\title{
Modulation of gut microbiota protects against viral respiratory tract infections: a systematic review of animal and clinical studies
}

\author{
Hai Yun Shi ${ }^{1}$ Xi Zhu ${ }^{2}$. Wei Lin Li ${ }^{3}$. Joyce W. Y. Mak ${ }^{4}$ Sunny H. Wong ${ }^{4}$. Sheng Tao Zhu ${ }^{1}$. Shui Long Guo ${ }^{1}$. \\ Francis K. L. Chan ${ }^{4,5,6} \cdot$ Shu Tian Zhang ${ }^{1} \cdot$ Siew C. Ng$^{4,5,6}$
}

Received: 10 November 2020 / Accepted: 16 February 2021 / Published online: 14 April 2021

○) Springer-Verlag GmbH Germany, part of Springer Nature 2021

\begin{abstract}
Background Earlier studies suggest that probiotics have protective effects in the prevention of respiratory tract infections (RTIs). Whether such benefits apply to RTIs of viral origin and mechanisms supporting the effect remain unclear.

Aim To determine the role of gut microbiota modulation on clinical and laboratory outcomes of viral RTIs.

Methods We conducted a systematic review of articles published in Embase and MEDLINE through 20 April 2020 to identify studies reporting the effect of gut microbiota modulation on viral RTIs in clinical studies and animal models. The incidence of viral RTIs, clinical manifestations, viral load and immunological outcomes was evaluated.

Results We included 58 studies (9 randomized controlled trials; 49 animal studies). Six of eight clinical trials consisting of 726 patients showed that probiotics administration was associated with a reduced risk of viral RTIs. Most commonly used probiotics were Lactobacillus followed by Bifidobacterium and Lactococcus. In animal models, treatment with probiotics before viral challenge had beneficial effects against influenza virus infection by improving infection-induced survival (20/22 studies), mitigating symptoms (21/21 studies) and decreasing viral load (23/25 studies). Probiotics and commensal gut microbiota exerted their beneficial effects through strengthening host immunity.

Conclusion Modulation of gut microbiota represents a promising approach against viral RTIs via host innate and adaptive immunity regulation. Further research should focus on next generation probiotics specific to viral types in prevention and treatment of emerging viral RTIs.
\end{abstract}

Keywords Viral respiratory tract infections $\cdot$ Gut microbiota $\cdot$ Probiotics

\section{Abbreviations}

BALF

COVID-19 Coronavirus disease 2019

DCs Dendritic cells

FMT Fecal microbiota transplantation

HSCT Hematopoietic stem cell transplantation

Hai Yun Shi, Xi Zhu and Wei Lin Li share co-first authorship

Siew C. Ng

siewchienng@cuhk.edu.hk

1 Department of Gastroenterology, Beijing Friendship Hospital, Capital Medical University; National Clinical Research Center for Digestive Diseases, Beijing Digestive Disease Center, Beijing, China

2 Department of Urology, Beijing Friendship Hospital, Capital Medical University, Beijing, China

3 Department of Medicine, Division of Genetics, Cancer Research Institute, Beth Israel Deaconess Medical Center, Harvard Medical School, Boston, MA, USA

$\begin{array}{ll}\text { IFN } & \text { Interferon } \\ \text { Ig } & \text { Immunoglobulin } \\ \text { IL } & \text { Interleukin } \\ \text { MERS-CoV } & \begin{array}{l}\text { Middle East respiratory syndrome } \\ \text { coronavirus }\end{array} \\ \text { NK } & \text { Natural killer } \\ \text { RCTs } & \text { Randomized controlled trials }\end{array}$

4 Department of Medicine and Therapeutics, State Key Laboratory for Digestive Disease, Institute of Digestive Disease, Li Ka Shing Institute of Health Science, The Chinese University of Hong Kong, Hong Kong, China

5 Center for Gut Microbiota Research, Faculty of Medicine, The Chinese University of Hong Kong, Hong Kong, China

6 Microbiota I-Center (MagIC) Limited, The Chinese University of Hong Kong, Hong Kong, China 


$\begin{array}{ll}\text { RR } & \text { Rate ratio } \\ \text { RSV } & \text { Respiratory syncytial virus } \\ \text { RTIs } & \begin{array}{l}\text { Respiratory tract infections } \\ \text { SARS-CoV }\end{array} \\ \text { Severe acute respiratory syndrome } \\ \text { coronavirus }\end{array}$

\section{Introduction}

Viral respiratory tract infections (RTIs) are major global public health challenges because they are the most common causes of infectious diseases resulting in work and productivity loss $[1,2]$. Effective antiviral drugs and vaccinations are lacking for non-influenza respiratory viruses $[1,3]$. The outbreak of novel viruses causing high mortality, including severe acute respiratory syndrome coronavirus (SARS-CoV) in 2003, influenza A (H5N1) in 2005, Middle East respiratory syndrome coronavirus (MERS-CoV) in 2012, and influenza A (H7N9) in 2013 [4] and more recently, SARS-CoV-2 leading to novel coronavirus disease 2019 (COVID-19) has resulted in catastrophic outcomes. As of 30 Jan 2021, COVID-19 has infected over 102.6 million people and led to more than 2.2 million deaths worldwide. Given the challenges on both of the prevention and treatment of viral RTIs, it is important to identify effective and safe measures to protect against emerging infectious diseases.

Gut microbiota plays pivotal roles in establishing intestinal mucosal barrier function [5], shaping nutrient absorption and metabolism [6], and modulating host immunity [7]. Maintenance of microbiota homeostasis has been implicated to be crucial for creating colonization resistance to foreign pathogens [8]. Particularly, microbiota-mediated triggering, calibrating and functioning of both innate and adaptive immunity assist in facilitating protection against exogenous viruses $[9,10]$. In contrast, a dysregulated microbiota composition which loses elasticity and diversity is more likely to provoke impaired immune responses [11].

Previous systematic reviews have identified the protective effects of oral probiotics and prebiotics in the prevention of RTIs [12-16]. However, very few studies included in these systematic reviews included virological tests whereas the majority studies defined RTIs according to subjective or indirect measures, such as self-reported symptoms, visits to general practitioners, antibiotics use, or even school loss, through which viral and non-viral infections were unable to be differentiated [12-16]. The effects of gut microbiota modulation on tackling viral RTIs remain unclear. Therefore, we performed a systematic review focusing on viral RTIs whereby etiologies were confirmed by virology tests.
The aims of this systematic review were to (i) determine the efficacy of gut microbiota modulation using probiotics on outcomes of viral RTIs in clinical studies; and (ii) delineate the role of probiotics and the importance of commensal gut microbiota in protecting the host against viral RTIs in animal models.

\section{Methods}

\section{Search strategy}

This study was conducted according to the Preferred Reporting Items for Systematic Reviews and Meta-Analyses guidelines [17]. An electronic literature search was performed on Embase and Ovid MEDLINE using the following keyword combinations: ('virus' or 'Coronavirus') and 'infection' and ('microbiota' or 'microbiome' or 'probiotic' or 'prebiotic' or 'synbiotic'). The search was implemented without a starting date being applied but until 20 April 2020. The detailed searching strategy is provided in Additional file 1. Reference lists of original articles and relevant reviews were manually searched to identify additional studies for inclusion. After removal of duplicated references, initial screening of article titles and abstracts was undertaken by two independent investigators (HYS and XZ). Potential relevant articles were obtained in full text and reviewed independently. Disagreements were resolved through consensus and discussion with a third investigator (JWYM). Predefined criteria were used to determine eligibility for inclusion.

\section{Selection criteria}

We included interventional studies reporting the role of gut microbiota modulation on viral RTIs: (1) clinical studies on probiotics application in viral RTIs; (2) animal studies investigating the effects of gut microbiota manipulation on viral RTIs. Studies with clinical, virological, pathological or immunological outcomes were included. Studies were excluded if: (1) infecting organisms were not identified; (2) respiratory tract injury was caused by systemic viral infection (i.e. human immunodeficiency virus infection); (3) we were unable to separate viral RTIs from viral infections of other sites (i.e. gastrointestinal tract); (4) none of the outcomes (rate of RTIs, symptoms, viral load, respiratory pathology, virus-specific antibodies) were presented; (5) paper was published as conference abstract, review, letter, note, lecture, comment or editorial; (6) full texts were unavailable; (7) the paper was not in English language. 


\section{Data extraction}

Two investigators (HYS and XZ) extracted data and entered it into a spreadsheet independently. A third investigator (WLL) evaluated the accuracy of this process. The collected data included the first author, country, study type, virus, subjects, sample size, age, sex, methodology of gut microbiota manipulation (details of strains used for intervention, administration form, administration dose, treatment duration, follow-up duration), outcomes and immune response.

\section{Risk of bias assessment}

All included clinical trials were independently assessed for bias using the Cochrane Handbook for Systematic Review of Interventions [18] by 2 investigators (HYS and XZ), with disagreements resolved by a third investigator (JWYM). Bias was assessed on selection (randomization, allocation concealment), performance (blinding of participants and personnel), detection (blinding of outcome assessment), attrition (incomplete outcome data), reporting (selective reporting), and other bias (e.g., funding).

\section{Results}

\section{Study selection}

Overall, 1719 records were retrieved, and an additional six records were identified from reference lists of the related articles. After removal of 70 duplicates, 1655 records were screened according to the general criteria. Based on titles and abstracts, 1555 citations were rejected during the initial screen. Full texts of the remaining 100 articles were further reviewed for eligibility, and an additional 41 articles were excluded. Finally, our systematic review included 59 articles from 58 studies (Figs. 1 and 2).

\section{Human trials}

Nine randomized controlled trials (RCTs) [19-28] involving 1240 healthy individuals assessed the efficacy of probiotics or prebiotics in preventing viral RTIs (Table 1). The nine trials reported the results of probiotics in individuals of different age groups: five $[19,20,22,24,26,27]$ focused on adults

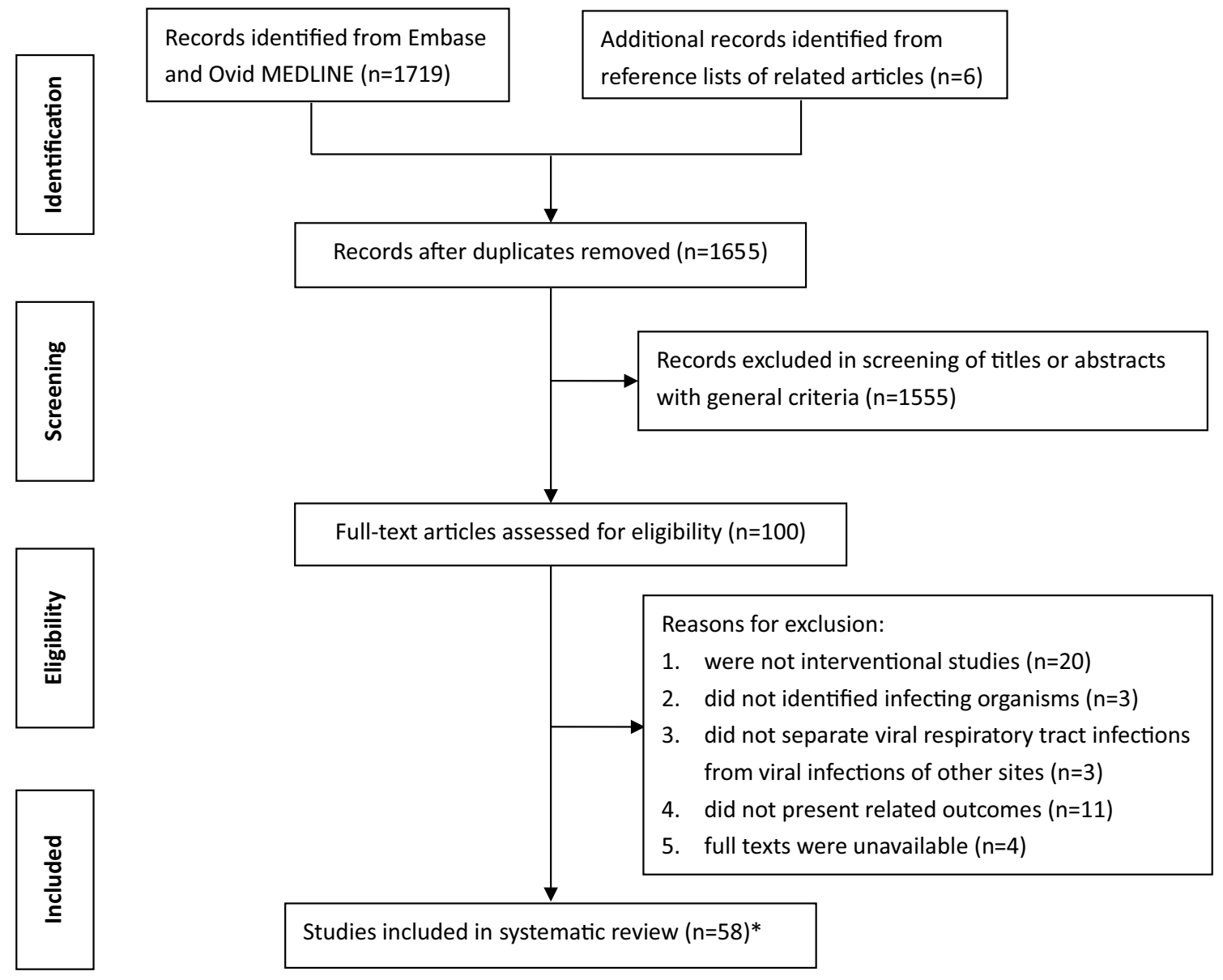

Fig. 1 Literature search and selection of included studies in this systematic review. * Fifty-nine articles from 58 studies 


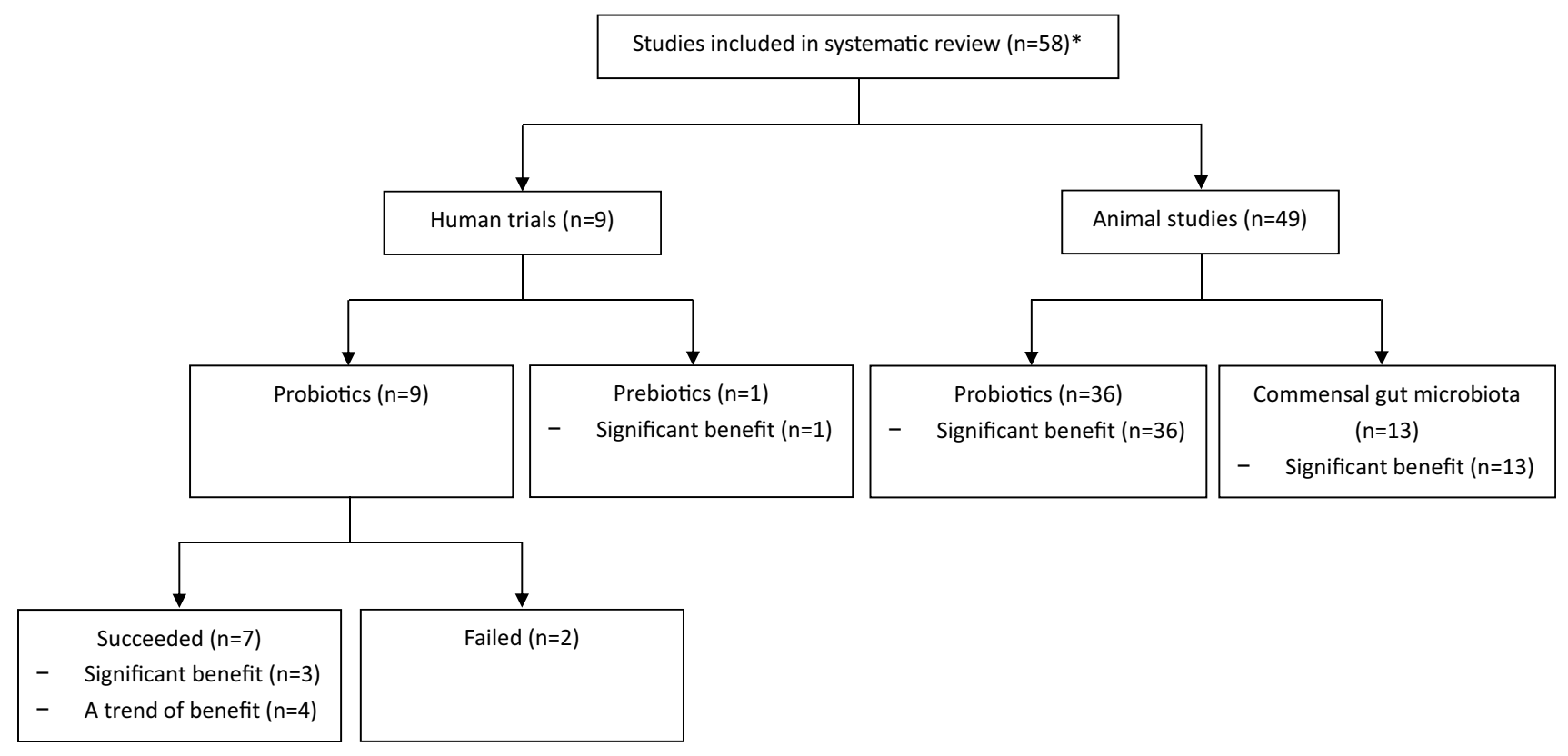

Fig. 2 Categorization of included studies. * Fifty-nine articles from 58 studies

( $n=675)$, two $[21,28]$ on elderly subjects $(n=303)$, one on children [23] $(n=194)$ and one on preterm infants $(n=68)$ [25]. Lactobacillus was the most commonly used probiotics [19, 21-25, 27, 28], followed by Bifidobacterium [20, 24] and Lactococcus [26]. One trial also evaluated the efficacy of prebiotics (galacto-oligosaccharide and polydextrose) in preventing viral RTIs [25].

\section{Effect of probiotics in reducing risk of infection}

Of the eight studies with viral infection rate reported, the protective effects of probiotics in reducing the infection risk were noted in six studies [20-22, 24, 25, 27], although statistical significance was not observed in four of them [20-22, 27]. In a small study, there was less frequent occurance of picornaviruses (mainly rhinovirus) infection after three months of probiotics (Lactobacillus rhamnosus GG and Bifidobacterium animalis ssp. lactis BB-12) intake (5/13 vs. $15 / 17$ of control group, $p=0.0069)$ among military recruits [24]. Another study found that among preterm infants, the rate of viral RTIs was reduced in infants with administration of probiotic (Lactobacillus rhamonosus GG) $(52.4 \%$ ) than those on placebo (83.3\%) during a 12-month follow-up [25]. Frequent ( $>3$ episodes) viral RTIs were less commonly found in probiotic group (9.5\%) than placebo group $(33.3 \%)$. The risk of rhinovirus infection was decreased in probiotic group (rate ratio [RR] $0.49 ; p=0.051$ ), compared with placebo group. In sensitivity analysis assuming that missing subjects remained healthy throughout the study period, the incidence of rhinovirus-induced episodes was significantly lower in probiotic group, compared with that in placebo group (RR $0.43 ; p=0.041$ ).

\section{Effect of probiotics on respiratory viral load}

Three studies evaluated the impact of probiotics on viral load [19, 20, 25]. Two of these studies performed intranasal rhinovirus inoculation on healthy adults after 3 to 4 weeks of probiotics administration [19, 20]. The larger study with 115 subjects showed that pretreatment with 4 weeks of Bifidobacterium was associated with a significant reduction in nasal lavage virus titers $(p=0.03)$ and the proportion of subjects with virus shedding in nasal secretion was lower in the probiotic than placebo group $(76 \%$ vs. $91 \% ; p=0.04)$ [20]. A separate small study showed a tendency towards a lower viral load in subjects pretreated with 3 weeks of Lactobacillus [19]. Among preterm infants, there were no significant differences on rhinovirus load between the Lactobacillus rhamonosus GG and placebo groups [25]. During symptomatic rhinovirus episodes, the median time for virus eradication was $10-15$ days in the probiotic group, whereas it was more than 15 days in the placebo group, although the difference did not reach a statistical significance [25].

\section{Effect of probiotics on clinical symptoms of viral infections}

Four studies investigated the effect of probiotics on clinical symptoms caused by viral RTIs in a total of 441 subjects [20, 22, 23, 25]. One study showed a trend towards improved symptoms during the five days following rhinovirus 


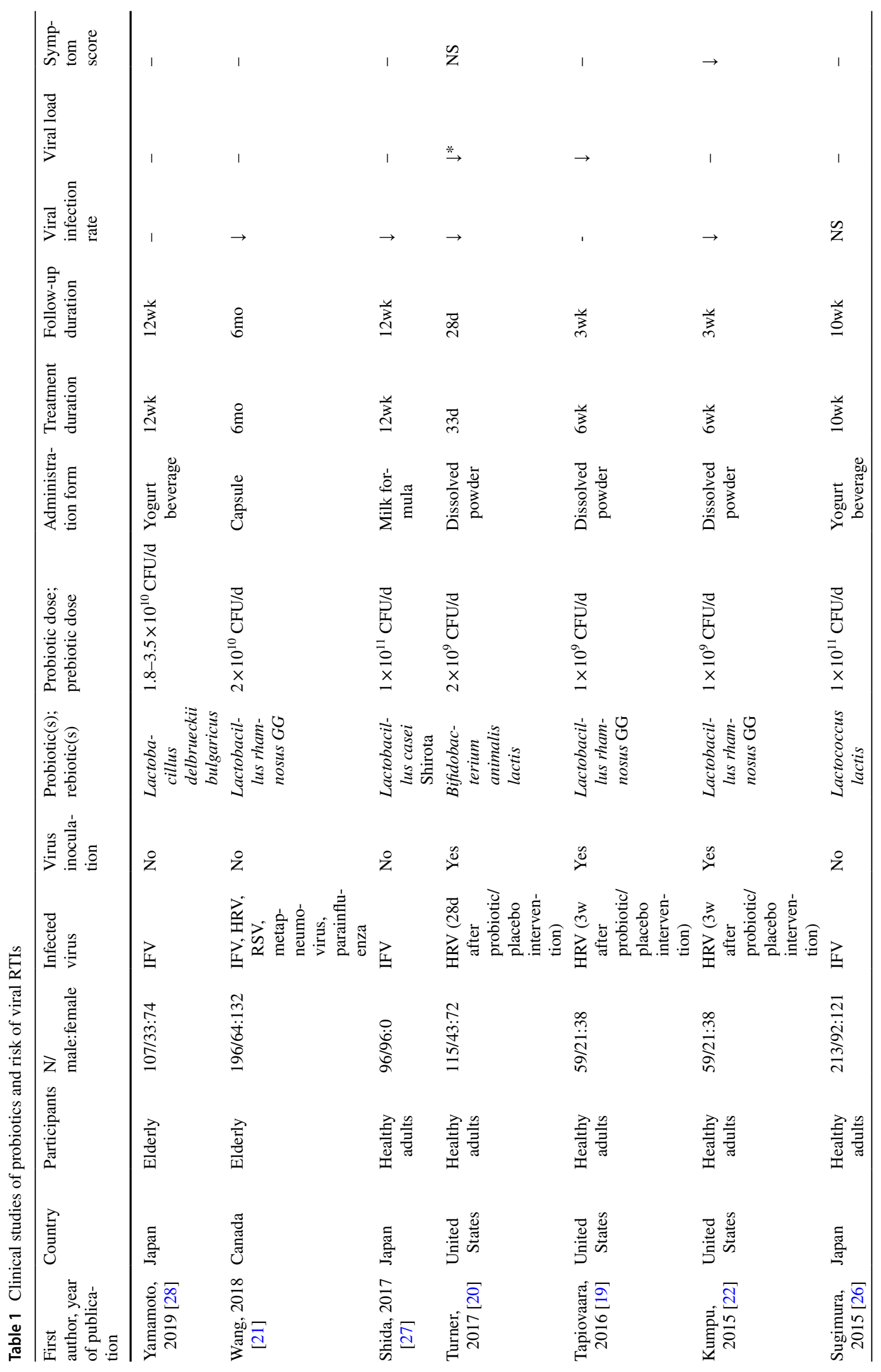




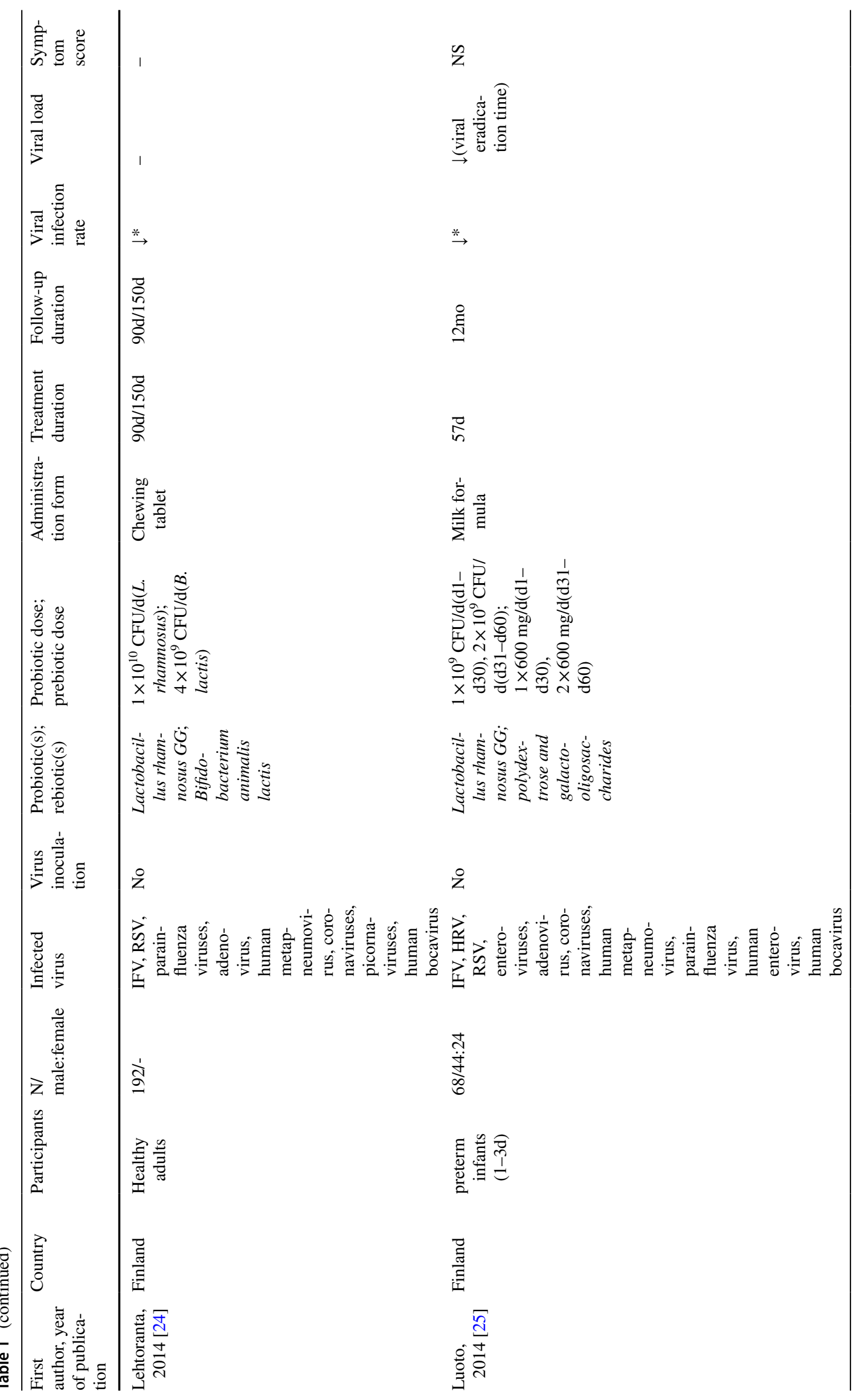




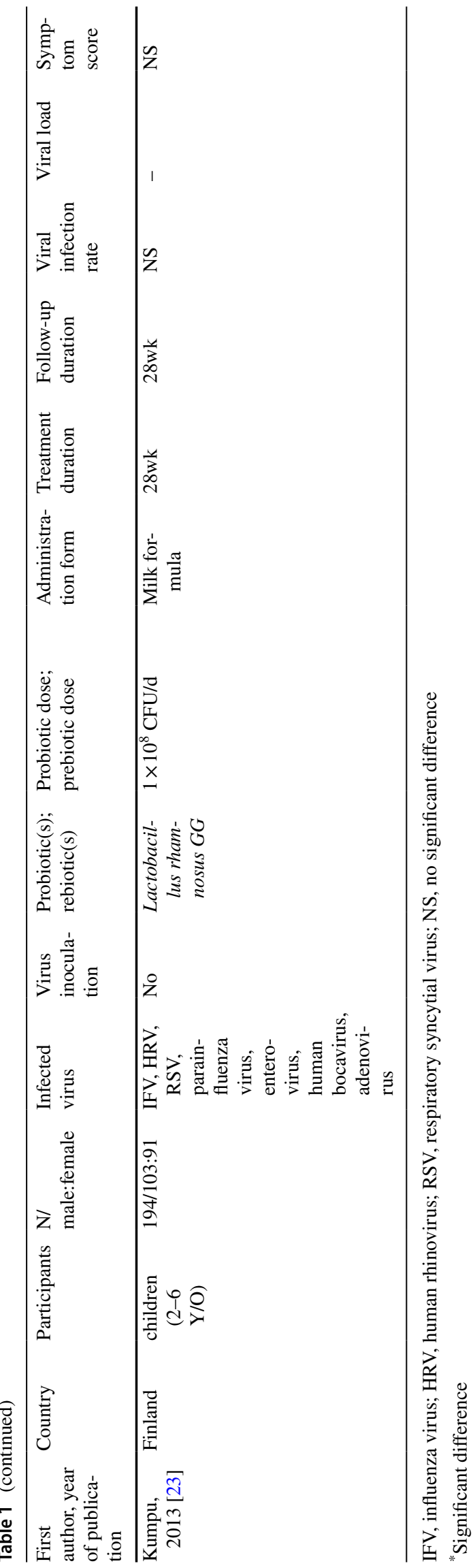

inoculation in probiotic group [22], the overall results of the four studies failed to identify a significant protective effect of probiotics on alleviating the severity of viral infectioninduced RTI symptoms.

\section{Effect of prebiotics in the prevention of viral infections}

Only one study investigated the effects of prebiotics (galactooligosaccharide and polydextrose) in the prevention of viral RTIs [25]. Among preterm infants, prebiotics significantly reduced the risk of viral RTIs ( $39.1 \%$ vs. $83.3 \%, p=0.005$ ) and frequent viral RTIs ( $0 \%$ vs. $33.3 \%, p=0.005$ ), compared with placebo during a 12-month follow-up. The incidence of rhinovirus infection was significantly lower in prebiotic group than that in placebo group (RR 0.31, $p=0.003$ ). In sensitivity analysis, assuming that missing subjects remained healthy throughout the study period, the incidence of rhinovirus-induced episodes was significantly lower in prebiotic group, compared with placebo group (RR 0.29, $p=0.010$ ). There was no significant difference on rhinovirus load between the prebiotic and placebo groups. Among symptomatic patients, the median time for virus eradication was shorter in the prebiotic group (10-15 days) than that (15 days) in the placebo group, although the difference did not reach a statistical significance. The severity of clinical symptoms was not significantly different between the prebiotic and placebo groups.

\section{Risk of bias assessment}

Summary of the risk of bias for the clinical studies was demonstrated in Table 2 . There were 4 studies (5 articles) [19, $22,23,26,27]$ at unclear risk for selection bias (did not describe the methods used to generate random sequence or conceal the allocation sequence in sufficient details). The risk of performance bias was high in one study [27] (lack of identical placebo). For 7 studies (8 articles) [19-25, 28], there was unclear risk of attribution bias (missing data on the main outcome, no formal sample size calculation or unmet predefined sample size). There were 7 studies ( 8 articles) $[19,21-23,25-28]$ at unclear risk of other bias because the studies were funded by of the probiotic manufacturer or distributor, or the authors were employed by the provider of the study product.

\section{Animal studies}

\section{Probiotics and outcomes of viral RTIs in animal models}

A total of 36 studies investigated the effects of oral administration of probiotics on outcomes of viral RTIs in animal models (Table 3). Probiotics were administered prior to viral 
Table 2 Risk of bias summary for the randomized controlled trials in humans

\begin{tabular}{|c|c|c|c|c|c|c|c|}
\hline $\begin{array}{l}\text { First author, year } \\
\text { of publication }\end{array}$ & $\begin{array}{l}\text { Random } \\
\text { sequence gen- } \\
\text { eration (selection } \\
\text { bias) }\end{array}$ & $\begin{array}{l}\text { Allocation } \\
\text { concealment } \\
\text { (selection bias) }\end{array}$ & $\begin{array}{l}\text { Blinding of } \\
\text { participants and } \\
\text { personnel (per- } \\
\text { formance bias) }\end{array}$ & $\begin{array}{l}\text { Blinding of out- } \\
\text { come assessment } \\
\text { (detection bias) }\end{array}$ & $\begin{array}{l}\text { Incomplete } \\
\text { outcome data } \\
\text { (attrition bias) }\end{array}$ & $\begin{array}{l}\text { Selective report- } \\
\text { ing (reporting } \\
\text { bias) }\end{array}$ & Other bias \\
\hline $\begin{array}{l}\text { Yamamoto, } 2019 \\
\text { [28] }\end{array}$ & $\mathrm{L}$ & $\mathrm{L}$ & $\mathrm{L}$ & $\mathrm{L}$ & $\mathrm{U}$ & $\mathrm{L}$ & $\mathrm{U}$ \\
\hline Wang, 2018 [21] & $\mathrm{L}$ & $\mathrm{L}$ & $\mathrm{L}$ & $\mathrm{L}$ & $\mathrm{U}$ & $\mathrm{L}$ & $\mathrm{U}$ \\
\hline Shida, 2017 [27] & $\mathrm{U}$ & $\mathrm{U}$ & $\mathrm{H}$ & $\mathrm{L}$ & $\mathrm{L}$ & $\mathrm{L}$ & $\mathrm{U}$ \\
\hline Turner, 2017 [20] & $\mathrm{L}$ & $\mathrm{L}$ & $\mathrm{L}$ & $\mathrm{L}$ & $\mathrm{U}$ & $\mathrm{L}$ & $\mathrm{L}$ \\
\hline $\begin{array}{l}\text { Tapiovaara, } 2016 \\
\text { [19] }\end{array}$ & $\mathrm{L}$ & $\mathrm{U}$ & $\mathrm{L}$ & $\mathrm{L}$ & $\mathrm{U}$ & $\mathrm{L}$ & $\mathrm{U}$ \\
\hline $\begin{array}{l}\text { Kumpu, } 2015 \\
\text { [22] }\end{array}$ & $\mathrm{L}$ & $\mathrm{U}$ & $\mathrm{L}$ & $\mathrm{L}$ & $\mathrm{U}$ & $\mathrm{L}$ & $\mathrm{U}$ \\
\hline $\begin{array}{l}\text { Sugimura, } 2015 \\
\text { [26] }\end{array}$ & $\mathrm{L}$ & $\mathrm{U}$ & $\mathrm{L}$ & $\mathrm{L}$ & $\mathrm{L}$ & $\mathrm{L}$ & $\mathrm{U}$ \\
\hline $\begin{array}{l}\text { Lehtoranta, } 2014 \\
\text { [24] }\end{array}$ & $\mathrm{L}$ & $\mathrm{L}$ & $\mathrm{L}$ & $\mathrm{L}$ & $\mathrm{U}$ & $\mathrm{L}$ & $\mathrm{L}$ \\
\hline Luoto, 2014 [25] & $\mathrm{L}$ & $\mathrm{L}$ & $\mathrm{L}$ & $\mathrm{L}$ & $\mathrm{U}$ & $\mathrm{L}$ & $\mathrm{U}$ \\
\hline $\begin{array}{l}\text { Kumpu, } 2013 \\
\text { [23] }\end{array}$ & $\mathrm{L}$ & $\mathrm{U}$ & $\mathrm{L}$ & $\mathrm{L}$ & $\mathrm{U}$ & $\mathrm{L}$ & $\mathrm{U}$ \\
\hline
\end{tabular}

$\mathrm{L}$, low risk; $\mathrm{H}$, high risk; $\mathrm{U}$, unclear risk

infection in all of the studies. The majority of the studies ( $n=28$ ) used Lactobacillus [9, 29-55], followed by Bifidobacterium [56-58], Enterococcus [59-61] or Lactococcus $[62,63]$. Thirty-one studies investigated the outcome of probiotics in influenza virus [9, 29, 32-49, 51-53, 55-61, 63], four studies targeted respiratory syncytial virus (RSV) [30, $31,36,54]$, whilst the remaining studies focused on parainfluenza virus [62] and avian influenza virus [50].

\section{Probiotics improved outcomes of mice infected with influenza virus}

Twenty-two studies reported the effect of probiotics on survival after virus challenge $[9,32,33,35,37,42-49,51,53$, 56-61, 63]. Amongst the 22 studies, 20 showed decreased mortality rates $[35,37,42,46-49,51,53,56-61,63]$ or prolonged survival time [33, 43-45] in mice, which were given probiotics. Five studies revealed a dose-dependent manner of Lactobacillus in improving survival [35, 44, 45, 47, 49]. One study found that live Lactobacillus spp. were superior to the inactivated ones in increasing survival rate [35].

Twenty-one studies evaluated the impact of probiotics on infection-induced symptoms [9, 29, 32-34, 37-42, 47-49, $53,55-57,59,60,63]$. Being the most commonly reported symptom, weight loss was significantly mitigated in mice treated with probiotics in 18 studies [29, 32-34, 37, 39-42, 47-49, 55-57, 59, 60, 63]. Eleven studies scaled the symptoms using clinical scores based on fur appearance, eyelid, behavior or other indices, such as breath and body temperature, and all of these studies demonstrated significant improvement in mice given probiotics [9, 29, 34, 37-39, 41, 53, 55-57].

Twenty-five studies investigated the effect of probiotics on influenza viral load. Virus titers were lower in 23 studies tested in lungs [9, 33, 35-42, 44, 45, 47-49, 55, 56, 59, 63], bronchoalveolar lavage fluid (BALF) [40, 46, 47, 57], and nasal washings $[52,53]$ of mice pretreated with Lactobacillus [9, 32, 33, 35-49, 52, 53, 55], Bifidobacterium [56, 57], Enterococcus [59] or Lactococcus [63]. A dose-dependent manner of Lactobacillus was also observed in suppressing viral replication in lungs [40, 44, 49].

\section{Immune responses underlying the effects of probiotics on mice infected with influenza virus}

Seventeen studies discussed the intimate involvement of immune cells in probiotic-mediated protection against influenza virus infection $[27,29,31,33,39,46,48,52,53,55$, 57, 58, 62, 64-67]. In particular, studies reported increased natural killer (NK) cell activities [27, 39, 46, 52, 53, 57, 64, 67], or decreased infiltrating macrophages and neutrophils in BALF [33] upon probiotic administration. Meanwhile, two studies with Lactobacillus or Lactococcus administration dramatically increased the recruitment of dendritic cells (DCs) [29, 62].

Twelve studies reported the contribution of interferon$\alpha / \beta$ (IFN- $\alpha / \beta)$ to immune defenses against viral infections triggered by probiotic administration $[9,26,30,34,45,54$, 57, 62, 68-71]. Of these, studies regard to Lactobacillus [9, 30, 34, 45, 54], Lactococcus [26, 62], Bifidobacterium [57], 


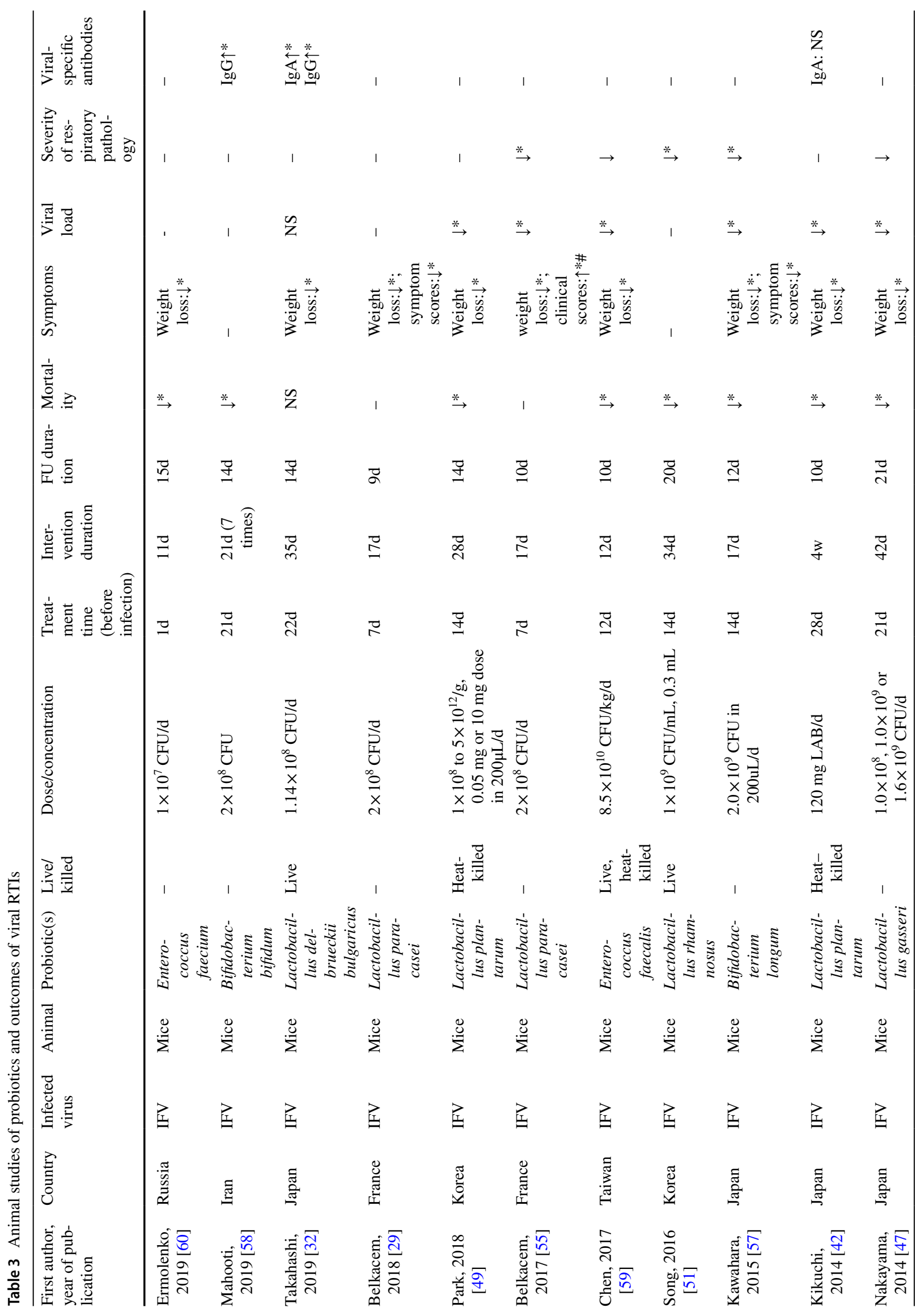




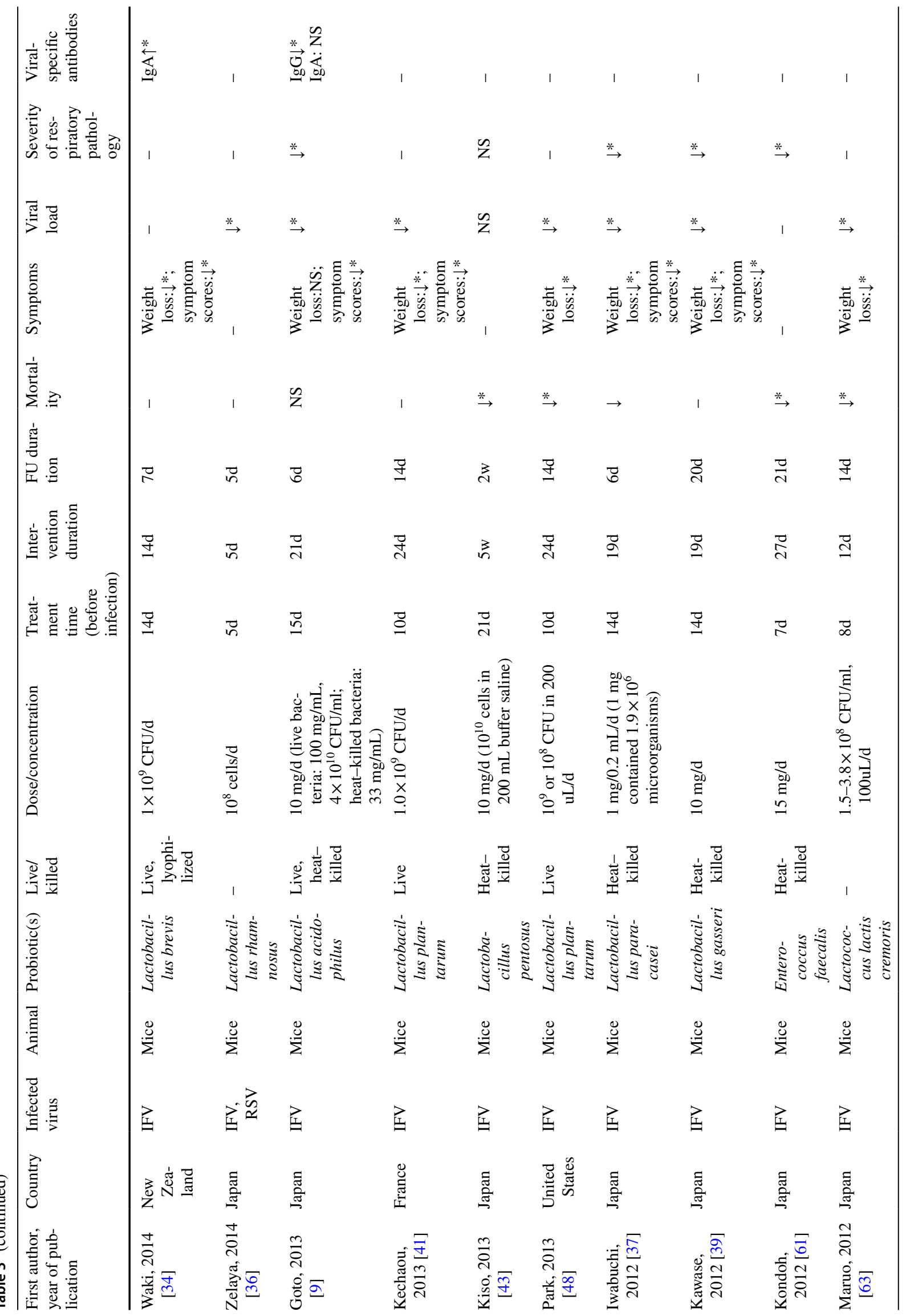




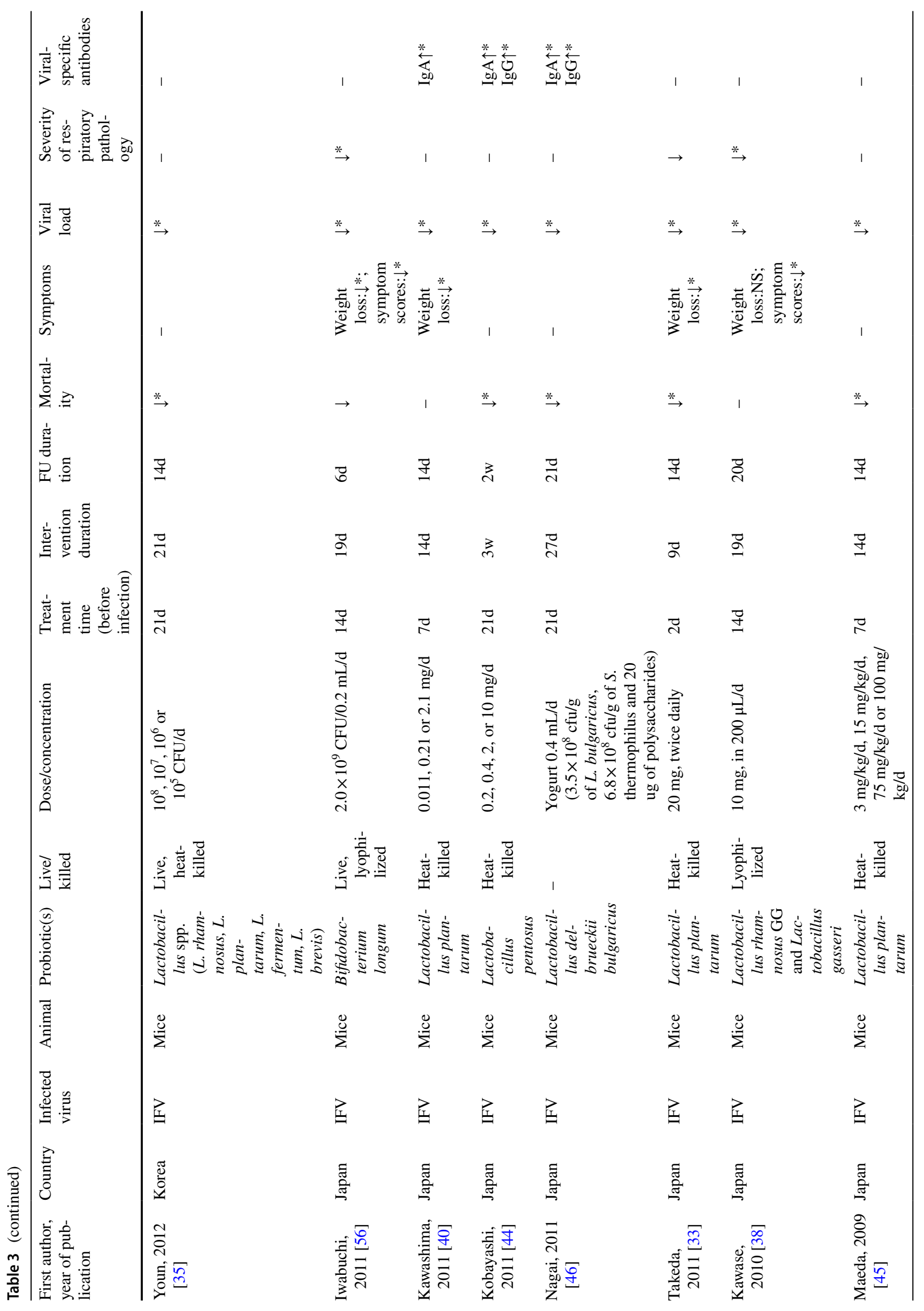




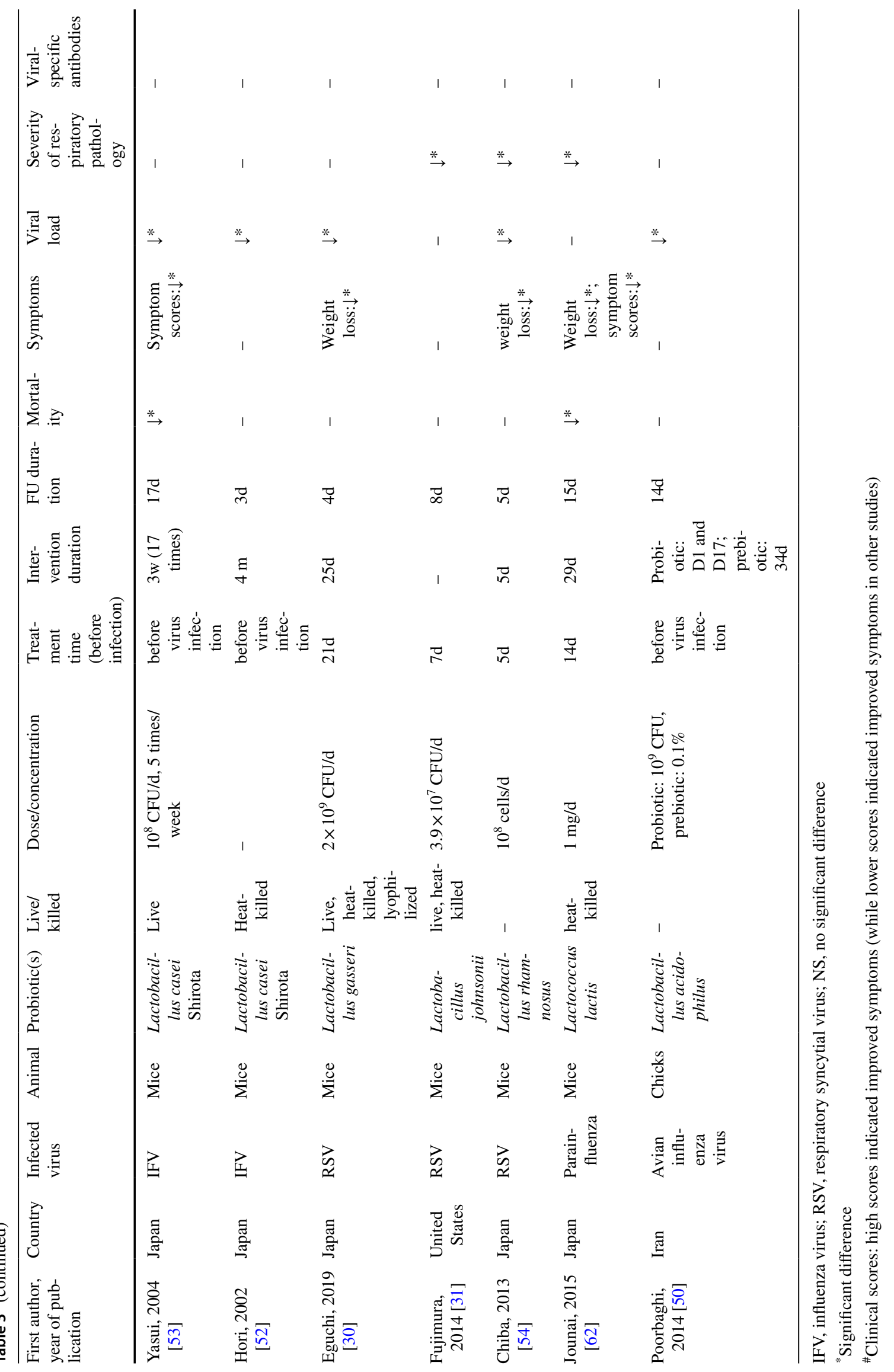


or Enterococcus [71] administration showed increased production of either IFN- $\alpha$ or IFN- $\beta$. Sixteen studies addressed the alteration of IFN- $\gamma$ in respiratory virus infected mice administered with probiotics $[26,33,39,48,51,52,54-58$, $69,71-74]$. There are 12 studies declared the increase of IFN- $\gamma$ after administration of probiotic Lactobacillus [30, $32,33,39,48,51,52,54,55]$, Bifidobacterium $[57,58]$, or Bifico [73] (a probiotic mixture consisting Bifidobacterium, Lactobacillus acidophilus, and Enterococcus). Seven studies indicated the roles of TNF- $\alpha$ in assisting immune defense against influenza virus infection [33, 36, 45, 48, 51, 52, 57]. Only one study detected increased production of TNF- $\alpha$ by nasal lymphocytes with administration of Lactobacillus [52]. Conversely, 6 of the studies consistently reported decreased TNF- $\alpha$ level, with 4 of them were being administered with Lactobacillus [33, 48, 74], 2 of them with Enterococcus [61, 71], while one of them with Bifidobacterium [57].

Seventeen studies reported the roles of dominant interleukins (ILs) in protective immune responses [9, 29, 33, 36, 48, $51,53-59,61,71,73,74]$. Four studies demonstrated that administration of Lactobacillus led to immune regulatory responses by upregulating IL-10 [36, 54, 55, 74]. Eight of the studies reported decrease in IL- 6 after administration of Lactobacillus [33, 48], Bifidobacterium [56-58], Enterococcus [59, 71], or Bifico [73]. More specifically, strain-specific effects were observed in animal studies conducted using Lactobacillus rhamnosus M21 and CRL1505, respectively [51, 54], as Lactobacillus rhamnosus M21 mainly induces IL-12 increase while Lactobacillus rhamnosus CRL1505 promotes secretion of anti-inflammatory cytokine IL-10.

Eight studies [9, 32, 34, 40, 42, 44, 46, 58] tested the levels of virus-specific antibodies. Five of them reported increased influenza virus-specific immunoglobulin A (IgA) levels in the BALF [34, 40, 44, 46], and immunoglobulin $\mathrm{G}(\mathrm{IgG})$ titers in BALF $[40,44,46]$ and serum $[40,44,58]$ were elevated in the probiotic (Lactobacillus or Bifidobacterium) group, compared with non-probiotic group. Probiotic feeding stimulated not only the production of influenza virus-specific $\operatorname{IgA}$ and $\operatorname{IgG}$ titers, but also accelerate their neutralization activities in serum and BALF in mice treated with oseltamivir [32]. One study revealed a dose-dependent manner of probiotics in stimulating influenza virus-specific IgA and IgG production [44].

\section{Probiotics improved outcomes of mice infected with RSV}

All of the four studies [30, 31, 36, 54] focused on RSV infection showed that Lactobacillus protected mice against RSV infection with alleviated body weight loss [30, 54], suppressed pulmonary RSV load [30, 36, 54], and milder pathological changes in lungs [31,54]. Live probiotics were superior to inactivated probiotics in reducing pulmonary histopathological inflammation [31].

\section{Commensal gut microbiota and the outcomes of viral RTls} in animal models

A total of thirteen studies investigated the influence of commensal gut microbiota on the outcomes of viral RTIs in animal models (Table 4). Of these studies, ten focused on influenza virus $[8,65,66,68,73,75-79]$, and the remaining studies were on RSV [80], parainfluenza virus [64] and avian influenza virus [81].

All of the ten studies focused on influenza virus demonstrated beneficial effects of commensal gut microbiota against viral infection $[8,65,66,68,73,75-79]$. In one study, natural gut microbiota from wild mice protected the recipient laboratory mice against influenza virus infection, manifested as reductions in mortality, weight loss, lung viral titers and respiratory immune-mediated pathology [8]. Depletion of intestinal commensal bacteria resulted in increased mortality [65, 79], greater weight loss [65, 75, 79], higher virus load $[65,66,68,75,76,78,79]$ and more severe inflammation in lungs $[65,73,78]$ of animals encountering viral challenge. In particular, antibiotic treatment by either cocktail (ampicillin, gentamicin, metronidazole, neomycin, vancomycin) $[65,66]$ or single antibiotic neomycin [66] both reduced $\mathrm{CD}^{+}$or $\mathrm{CD} 8^{+} \mathrm{T}$ cells. On the contrary, restoration of gut microbiota by probiotics (Bifico) supplementation [73], fecal microbiota transplantation (FMT) [79] or even commensal fungi (Candida albicans or Saccharomyces cerevisiae) colonization [77] was able to alleviate the severity of viral infection deteriorated by gut dysbiosis.

\section{Discussion}

To the best of our knowledge, this work is the first systematic review to report the role of gut microbiota manipulation on the risk and outcomes of viral RTIs. We found that modulation of gut microbiota may prevent viral RTIs in humans. Animal studies showed that treatments with probiotics before viral challenge were effective in improving the outcomes of viral RTIs, in terms of reducing infection-induced mortality, mitigating symptoms, decreasing viral load and boosting host immunity against viral infection. Disturbance of gut microbiota deteriorated in viral RTIs, which could be reversed by microbiota restoration. Furthermore, we have provided a data-driven explanation on the mechanisms by which gut microbiota modulation could impact viral RTIs.

Probiotics have been widely used to normalize perturbed gut microbiota and confer health benefits on hosts [82]. To focus on viral infections, we only included studies with positive virological tests or specific respiratory virus inoculation. Among the 8 RCTs in humans reporting virus infection rate, 6 showed decreased rates of RTIs in the probiotic group, suggesting probiotics are potentially promising agents to 


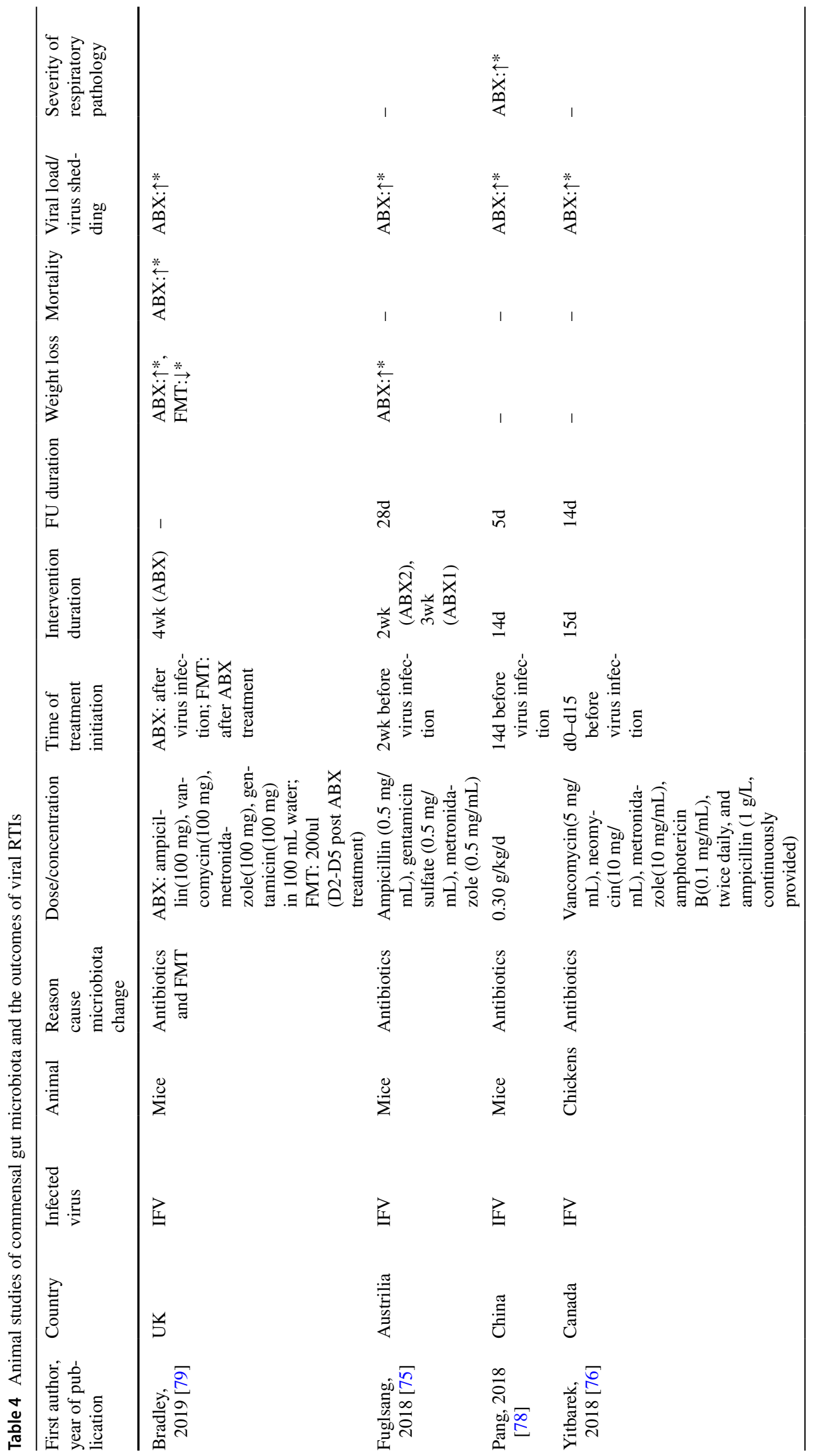




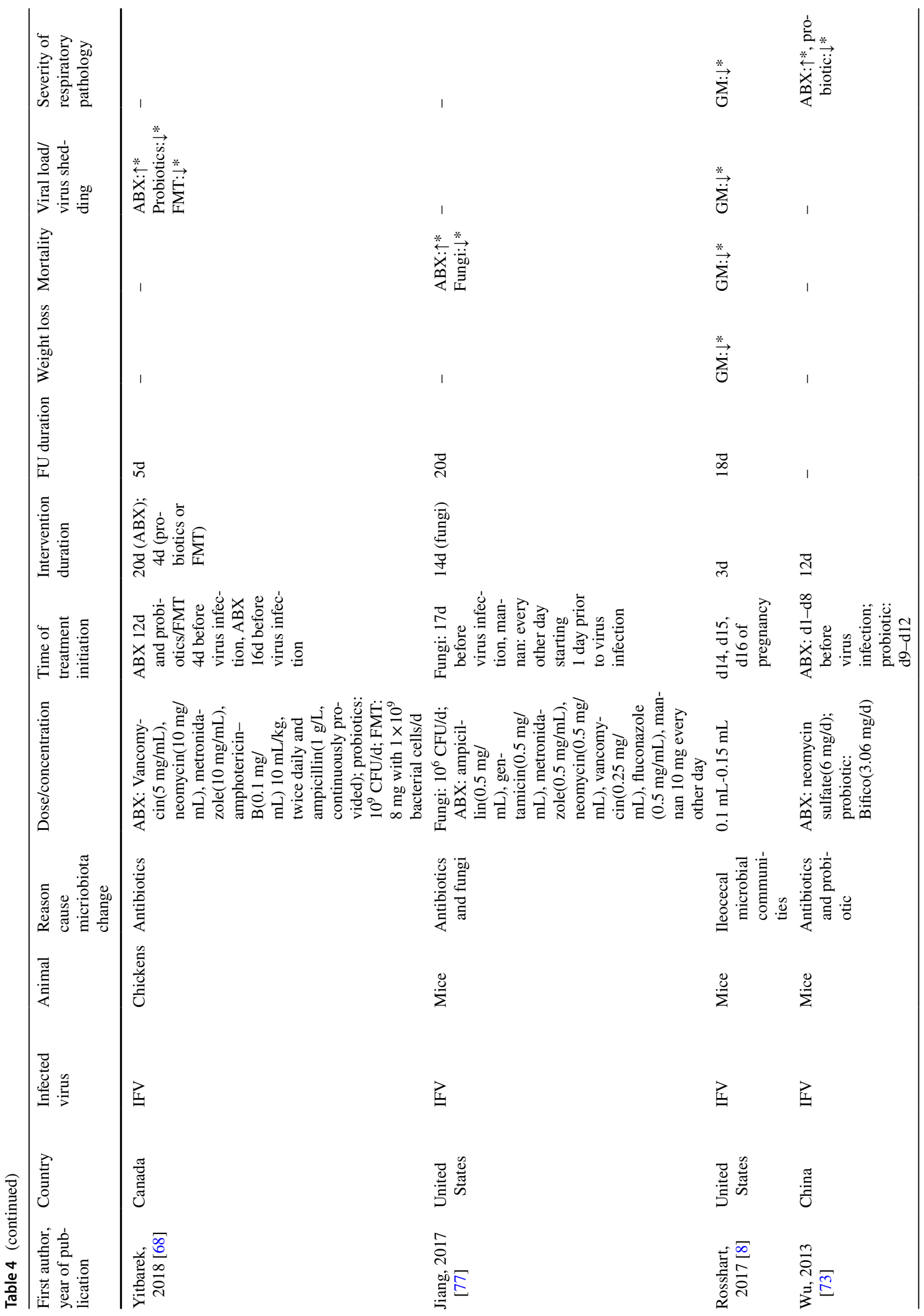




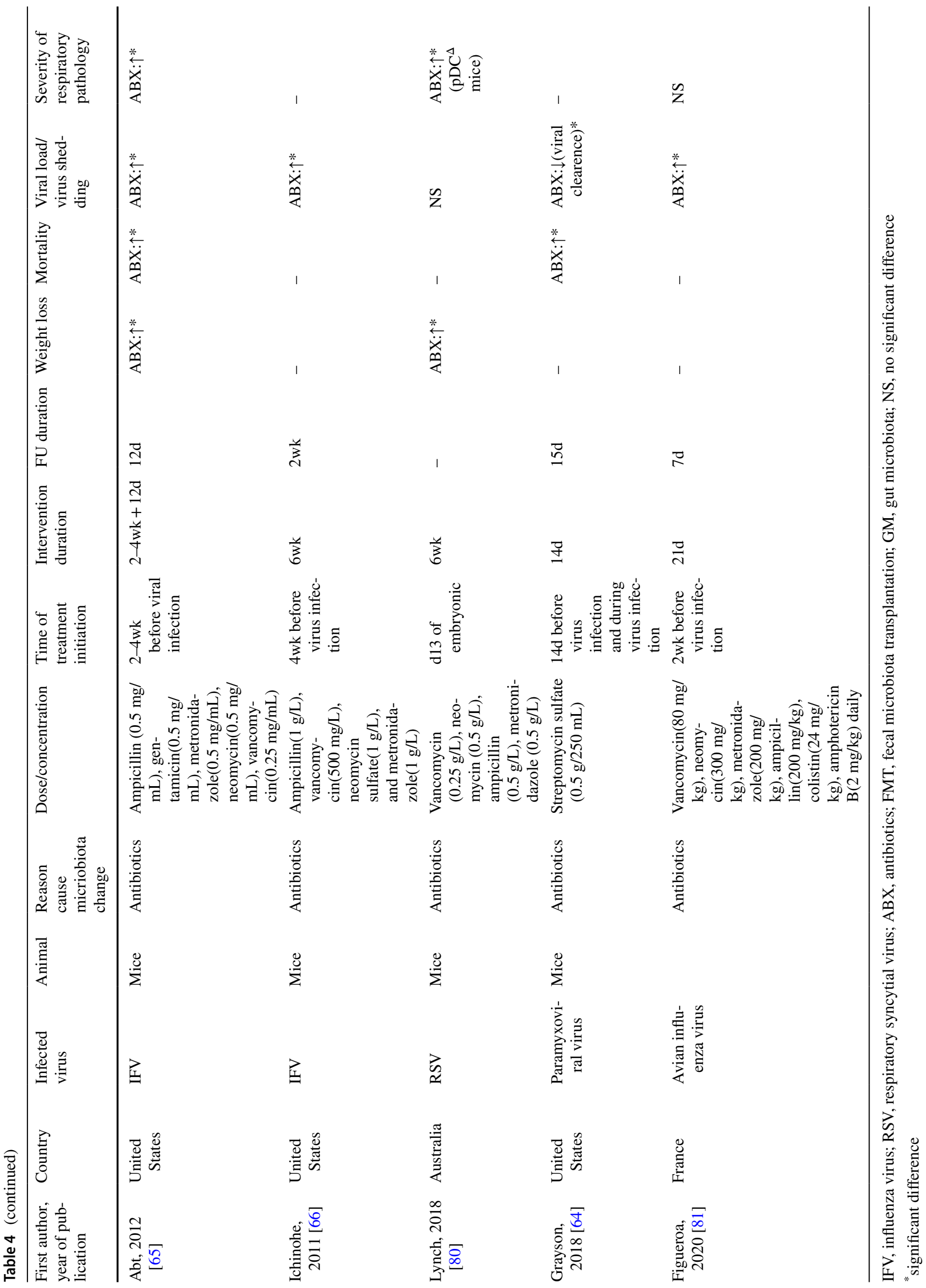


prevent viral RTIs. However, heterogeneity in studies had hindered direct comparison of individual study. Although current clinical studies did not show a significantly milder viral-induced symptoms in subjects on probiotics, animal studies illustrated a protective effect of Lactobacillus [9, 29-49, 51-54], Bifidobacterium [56-58], Enterococcus [59-61] and Lactococcus $[62,63]$ in alleviating the severity of viral infections. Mechanistically, probiotics could elicit protective responses against viral RTIs by inducing cytokine/chemokine production which further engage immune cells to modulate antiviral immunity, strengthening mucosal barrier through increasing mucin and tight junction molecules, etc. [83]. Probiotic-induced IFN- $\gamma$ have functions in regulating both innate and adaptive immunity, making it powerful in macrophages activation and wide-spectrum antiviral defenses [84]. Also, majority of probiotics strengthen host immunity by utilizing IL-4, IL-10, IL-12, IL-18 as immune-response mediators while producing IL- $1 \alpha / \beta$, IL- 6 , and $\mathrm{TNF} \alpha$ as pro-inflammatory factors, which in parallel depicted a preventative cytokine signature for evaluating probiotics [33, 48, 54, 57, 61, 71]. For example, oral administration of Bifidobacterium longum MM-2 elicit NK cell activation through upregulating pulmonary expressions of IFN- $\gamma$, IL-2, IL-12 and IL-18, which further result with antiinfluenza virus responses [57], while Enterococcus faecalis FK-23 oral administration, which exhibited improved survival rate in mouse model challenged by influenza A virus, upregulated anti-inflammatory IL-10 in lung tissues [61]. Probiotic boosts adaptive immune response with increased production of viral-specific IgA and IgG which is beneficial in defending viral RTIs. Besides innate and adaptive immunity, gut microbiota metabolism regulates inflammation through specific commensal bacteria that consume nondigestible dietary fibers and generate metabolites short-chain fatty acids (SCFAs, notably acetate, propionate, as well as butyrate) engaging in favoring mucosal barrier functionalities [80, 85-87]. However, these studies are all based on animal models. The mechanisms of probiotics in human viral RTIs need further investigations.

Data from animal studies have been predictive for the outcomes in subsequent human studies using the same strains. Oral administration of Lactobacillus delbrueckii bulgaricus OLL1073R-1 significantly prolonged the survival, reduced weight loss, decreased viral load and increased the antiinfluenza virus antibodies in mice [32, 46]. Evidence has shown that consuming yogurt fermented with Lactobacillus delbrueckii bulgaricus OLL1073R-1 may help prevent influenza A virus subtype $\mathrm{H} 3 \mathrm{~N} 2$ infection by increasing the production of H3N2-bound salivary IgA in the elderly [28]. Lactococcus lactis subsp. lactis JCM5805-fed mice showed a drastic improvement in survival rate, alleviation of infection related symptoms, and reduction in lung histopathology scores in parainfluenza virus infection [62]. A RCT on healthy adults had shown that Lactococcus lactis subsp. lactis JCM5805 intake significantly reduced the cumulative incidence days of major symptoms of an influenza-like illness [26]. Mice studies evidenced the effects of different Lactobacillus plantarum strains in improving the outcomes of influenza virus infection [33, 35, 40-42, 45, 48, 49]. Oral administration of heat-killed Lactobacillus plantarum L-137 enhanced protection against influenza virus infection by stimulating type I interferon production in mice [45]. A RCT conducted in subjects with high psychological stress levels showed that the incidence of upper RTI symptoms was significantly lower in those treated with heat-killed Lactobacillus plantarum L-137 [88]. The mechanistic read-outs observed in mice could also be reproduced in humans. However, the overall effects of probiotics were much clearer in the animal studies than in humans, which may be explained by the more heterogenous setting including differences in environmental and host factors that are known to influence the gut microbiome (e.g. diet, drugs, co-morbidities, followup duration, immune status, etc.) in human studies.

The effects of probiotics are influenced by multiplex factors. Probiotics confer a health benefit when administered in adequate amounts [82]. Lactobacillus rhamonosus GG was the first patented strain belonging to the genus Lactobacillus with a large number of research data as the basis for its use in combating against RTIs in humans [89]. For preventing viral RTIs, Lactobacillus rhamonosus GG at a daily dose of $10^{9} \mathrm{CFU}$ or above appeared to be effective in human trials $[21,22,24,25]$, whereas a dose of $10^{8} \mathrm{CFU}$ daily did not show a significantly positive role [23]. The administration of Lactobacillus spp. was shown to protect against influenza virus infection in a dose-dependent manner in mice $[35,40$, $44,45,47,49]$. It had been reported that the incidence and severity of upper RTIs negatively correlated with the duration of heat-killed Lactobacillus plantarum L-137 intake among healthy people [88]. Duration of probiotic treatment in the prevention of viral RTIs ranged from 33 days [20] to 28 weeks [23] in humans. However, due to scarcity of data and different types of formula used, we are unable to propose a minimal treatment dose and duration to ensure optimal outcome in fighting against viral RTIs at this stage. Although the overall safety profile of probiotics is satisfactory, it should be noted that probiotic use could be associated with a higher risk of infection and/or morbidity in vulnerable people [90]. There is an increasing interest in non-viable microorganism-inducible health benefits [91]. Animal studies demonstrated the beneficial effects of non-viable (mainly heat-inactivated) probiotics in viral RTIs $[9,33,37,39,40$, $42-45,49,52,59,61,62]$, although their effects appeared to be inferior to the live ones $[31,35]$. The effects of probiotics in eliciting cytokine profiles in human cells and stimulating host immune system against viral RTIs in mice are highly strain-specific [92]. Since the data of strains other 
than Lactobacillus rhamonosus GG were fairly limited in human studies, comparison of the strain-specific effects against viral RTIs in humans remains unavailable. Probiotic mixtures have been proved to be more effective than single-strain probiotics in inhibiting pathogen growth, due to an additive and more synergetic multispecies probiotic consortium [93]. Taking advantage of this finding, FMT, which transplants the great mixture of healthy gut ecosystem to recipients, represents the most powerful strategy of restoring a balanced gut microbiota [94]. However, potential risk of infections caused by undetected or unmonitored pathogens remains to be a major concern for its broad applications [93]. To overcome this problem, Petrof et al. developed a stool substitute consisting of 33 different purified intestinal bacteria isolated from a healthy donor, and successfully treated patients with antibiotic-resistant Clostridium difficile colitis [95]. Accelerated by massively parallel sequencing, our knowledge of the composition and function of the human gut microbiota has dramatically extended the range of organisms with potential health benefits. The next-generation probiotics, such as Faecalibacterium prausnitzii, Akkermansia muciniphila, Bacteroides fragilis and Bacteroides uniformis, have been identified to exert anti-inflammatory effects in animal models $[93,96]$.

Prebiotics are substrates selectively utilised by host micro-organisms conferring a health benefit [97]. RCTs had shown that the use of prebiotics in infants could reduce the risk of RTIs [25, 98-100]. Luoto et al. demonstrated that both probiotics (Lactobacillus rhamonosus $\mathrm{GG}$ ) and prebiotics (galacto-oligosaccharides and polydextrose) resulted in fewer episodes of viral RTIs, compared with placebo [25]. It is interesting to note that prebiotics tended to perform better than the probiotic in this trial. One possible reason might be the pre-existence of bifidobacteria-dominated infant gut microbiota, which strengthens the effect of "bifidogenic" prebiotics $[99,101]$. A study on mice model had shown that specific dietary prebiotic oligosaccaharides potentiated immune response against viral RTI102.

The gut-lung axis has been proposed in the pathogenesis of certain respiratory diseases [103]. Evidence has implied a gut-lung crosstalk in viral RTIs. Gut microbiota influences the susceptibility and severity of viral RTIs. Natural gut microbiota exhibiting more diverse microbiomes balanced systemic and local inflammatory responses upon lethal influenza virus challenge, resulting in higher survival rates and a milder disease course, compared with gut microbiota of laboratory mice from a restrictive environment [8]. Mice with depletion of commensal gut microbiota had significantly worse outcomes of viral RTIs [64, 65, 73, 75, 78, 79], which was reversed by restoration of gut microbiota with probiotics [73], FMT [79], and even commensal fungi colonization [77]. Clinical observational studies have also evidenced the importance of healthy gut microbiota in protecting against viral RTIs. Higher level of butyrate-producing gut bacteria significantly associated with less development of viral RTIs among kidney transplant recipients [104], and reduced risk of viral lower RTIs in patients post-allogeneic hematopoietic stem cell transplantation (HSCT) [105]. In another study involving patients underwent allogeneic HSCT and had viral RTIs post transplantation, the number of antibiotic-days was associated with progression to lower respiratory tract disease [106]. On the other hand, viral RTIs lead to gut microbiota alteration. Both influenza virus and RSV infections result in significant changes of gut microbiota in mice [72, 107, 108]. Influenza virus infection also resulted in decreased levels of SCFAs (the metabolic output of the gut microbiota) in both of the gut and blood in mice [86]. Oral administration of acetate protected mice against RSV infection [87]. Supplementation of acetate reduced lung pathology and improved survival rates of mice with influenza virus and Streptococcus pneumoniae superinfection [86].

COVID-19, caused by SARS-CoV-2, is a major public health crisis threatening the human world today. This novel coronavirus, along with the SARS-CoV and the MERS-CoV, belongs to Betacoronavirus genus [109]. Although patients typically present with fever and respiratory symptoms, the viruses can also affect the digestive system [110, 111]. Studies have reported frequencies of diarrhea ranging from 2.0 to $35.6 \%, 13.8$ to $73.3 \%$ and 11.5 to $32.0 \%$ among patients with COVID-19, SARS and MERS, respectively [110]. Gut microbial dysbiosis has been identified in COVID-19 patients, characterized by enrichment of opportunistic pathogens and depletion of beneficial commensals $[112,113]$. Gut microbiota alterations associated with disease severity. The severity of COVID-19 was positively correlated with the baseline abundance of Coprobacillus, Clostridium ramosum, and Clostridium hathewayi, and inversely correlated with that of Faecalibacterium prausnitzii (an antiinflammatory bacterium) [112]. Subjects with gut dysbiosis, such as elderly, immune-compromised patients and patients with other co-morbidities, tend to have more severe disease and poorer outcomes of COVID-19 [114]. It implies that gut microbiota modulation could potentially reduce disease severity. Most of the studies on gut microbiota modulation against viral RTIs were carried out on influenza virus as a prophylactic strategy, and no major evidence was available on its protective effect towards COVID-19, the importance of probiotics supplementation in COVID-19 treatment has been emphasized in the guidance given from China's National Health Commission [113]. However, not all probiotics are equivalent for efficacy [115]. A novel and more targeted approach to modulate gut microbiota as one of the therapeutic strategies for COVID-19 and its complications is much needed. In a recent study reported by d'Ettorre et al., among COVID-19 patients, oral administration of a probiotic mixture significantly reduced the risk of developing 
respiratory failure, and a trend towards reduced rates of mortality [116]. The Chinese University of Hong Kong team has developed an oral gut microbiota modulating formulation against COVID-19. In a pilot study, this formulation significantly improved clinical symptoms and reduced pro-inflammatory immune markers in COVID-19 patients [117]. Viral infections predispose patients to secondary bacterial infections, which often result in a more severe clinical course [118]. Empirical antibiotics are sometimes used for the management of viral infection when secondary bacterial infection is a concern. However, Zuo et al. revealed that antibiotics use led to further loss of salutary symbionts and exacerbation of gut dysbiosis in COVID-19 patients [112]. Animal studies have also proved the adverse influence of antibiotics in viral RTIs $[64,65,79]$. These results suggest clinicians to avoid unnecessary antibiotics use in the treatment of viral RTIs.

\section{Conclusion}

In conclusion, previous studies shed a light on the influence of gut microbiota on the occurrence and outcomes of viral RTIs. Gut microbiota modification presented a potential prophylactic and therapeutic avenue against viral RTIs through boosting immunity of hosts. However, research in this field is still in its infancy. High-quality clinical trials, translational studies and mechanism investigations are urgently needed. Unlike animal models, humans are highly heterogeneous in terms of diet, age, genetic background and gut microbiota configuration, and therefore may respond differently to the same intervention. With the development of new technologies, individualized gut microbiota modification will become available to address specific consumer needs and issues. Next-generation probiotics specific to viral strains and individualized conditions of the hosts may become a promising therapy in the prevention and treatment of viral RTIs in the near future.

Supplementary Information The online version contains supplementary material available at https://doi.org/10.1007/s00394-021-02519-x.

Acknowledgements All authors have read and approved the final manuscript.

Authors' contributions HYS, XZ and WLL developed the protocol; conducted database searches; retrieved the data; and wrote the manuscript. JWYM contributed to the protocol development; conducted database searches and literature screening; assisted in risk of bias assessment and manuscript preparation. SHW contributed to the consultation; assistance in protocol development and manuscript preparation. STZ (Zhu), SLG, FKLC and STZ (Zhang) contributed to the consultation; provided critical intellectual input in the study and manuscript. SCN contributed to the study concept and design; consultation; critically reviewed and revised the manuscript. All authors read and approved the final manuscript.
Funding This work was funded by the Beijing Nova Program (Z201100006820147); National Nature Science Foundation of China (81702960); Beijing Municipal Science \& Technology Commission (Z181100001718221); Beijing Municipal Administration of Hospitals' Youth Programme (QML20180102); Beijing Talents Fund (2017000021469G209); and InnoHK, The Government of Hong Kong, Special Administrative Region of the People's Republic of China.

\section{Declarations}

Conflicts of interest The authors declare that they have no conflict of interests.

\section{References}

1. Behzadi MA, Leyva-Grado VH (2019) Overview of current therapeutics and novel candidates against influenza, respiratory syncytial virus, and middle east respiratory syndrome coronavirus infections. Front Microbiol 10:1327. https://doi.org/10.3389/ fmicb.2019.01327

2. van Doorn HR, Yu H (2020) Viral respiratory infections. Hunter's Trop Med Emerg Infect Dis. https://doi.org/10.1016/b9780-323-55512-8.00033-8

3. Kodama F, Nace DA, Jump RLP (2017) Respiratory syncytial virus and other noninfluenza respiratory viruses in older adults. Infect Dis Clin North Am 31(4):767-790. https://doi.org/10. 1016/j.idc.2017.07.006

4. Beigel JH, Nam HH, Adams PL, Krafft A, Ince WL, El-Kamary SS, Sims AC (2019) Advances in respiratory virus therapeutics-a meeting report from the 6th isirv Antiviral Group conference. Antiviral Res 167:45-67. https://doi.org/10.1016/j.antiv iral.2019.04.006

5. Antonini M, Lo Conte M, Sorini C, Falcone M (2019) How the interplay between the commensal microbiota, gut barrier integrity, and mucosal immunity regulates brain autoimmunity. Front Immunol 10:1937. https://doi.org/10.3389/fimmu.2019.01937

6. Tremaroli V, Backhed F (2012) Functional interactions between the gut microbiota and host metabolism. Nature 489(7415):242249. https://doi.org/10.1038/nature11552

7. Atarashi K, Tanoue T, Shima T, Imaoka A, Kuwahara T, Momose Y, Cheng G, Yamasaki S, Saito T, Ohba Y, Taniguchi T, Takeda K, Hori S, Ivanov II, Umesaki Y, Itoh K, Honda K (2011) Induction of colonic regulatory $\mathrm{T}$ cells by indigenous Clostridium species. Science 331(6015):337-341. https://doi.org/10.1126/scien ce. 1198469

8. Rosshart SP, Vassallo BG, Angeletti D, Hutchinson DS, Morgan AP, Takeda K, Hickman HD, McCulloch JA, Badger JH, Ajami NJ, Trinchieri G, Pardo-Manuel de Villena F, Yewdell JW, Rehermann B (2017) Wild mouse gut microbiota promotes host fitness and improves disease resistance. Cell 171(5):10151028e1013. https://doi.org/10.1016/j.cell.2017.09.016

9. Goto H, Sagitani A, Ashida N, Kato S, Hirota T, Shinoda T, Yamamoto N (2013) Anti-influenza virus effects of both live and non-live Lactobacillus acidophilus L-92 accompanied by the activation of innate immunity. Br J Nutr 110(10):1810-1818. https://doi.org/10.1017/S0007114513001104

10. Belkaid Y, Hand TW (2014) Role of the microbiota in immunity and inflammation. Cell 157(1):121-141. https://doi.org/10. 1016/j.cell.2014.03.011

11. Correa-Oliveira R, Fachi JL, Vieira A, Sato FT, Vinolo MA (2016) Regulation of immune cell function by short-chain fatty acids. Clin Transl Immunol 5(4):e73. https://doi.org/10.1038/cti. 2016.17 
12. Lehtoranta L, Pitkäranta A, Korpela R (2014) Probiotics in respiratory virus infections. Eur J Clin Microbiol Infect 33(8):12891302. https://doi.org/10.1007/s10096-014-2086-y

13. King S, Glanville J, Sanders ME, Fitzgerald A, Varley D (2014) Effectiveness of probiotics on the duration of illness in healthy children and adults who develop common acute respiratory infectious conditions: a systematic review and meta-analysis. Br J Nutr 112(1):41-54. https://doi.org/10.1017/s0007114514000075

14. Hao Q, Dong BR (2015) Wu T (2015) Probiotics for preventing acute upper respiratory tract infections. Cochrane Database Syst Rev 2:CD006895

15. Wang Y, Li X, Ge T, Xiao Y, Liao Y, Cui Y, Zhang Y, Ho W, Yu G, Zhang T (2016) Probiotics for prevention and treatment of respiratory tract infections in children: a systematic review and meta-analysis of randomized controlled trials. Medicine (Baltimore) 95(31):e4509. https://doi.org/10.1097/md.0000000000 004509

16. Chan CKY, Tao J, Chan OS, Li HB, Pang H (2020) Preventing respiratory tract infections by synbiotic interventions: a systematic review and meta-analysis of randomized controlled trials. Adv Nutr (Bethesda, Md). https://doi.org/10.1093/advances/ nmaa003

17. McLeroy KR, Northridge ME, Balcazar H, Greenberg MR, Landers SJ (2012) Reporting guidelines and the American Journal of Public Health's adoption of Preferred Reporting Items for Systematic reviews and Meta-Analyses. Am J Public Health 102(5):780-784. https://doi.org/10.2105/ajph.2011.300630

18. Higgins JP, Altman DG, Gøtzsche PC, Jüni P, Moher D, Oxman AD, Savovic J, Schulz KF, Weeks L, Sterne JA (2011) The cochrane collaboration's tool for assessing risk of bias in randomised trials. BMJ (Clinical research ed) 343:d5928. https:// doi.org/10.1136/bmj.d5928

19. Tapiovaara L, Kumpu M, Makivuokko H, Waris M, Korpela R, Pitkaranta A, Winther B (2016) Human rhinovirus in experimental infection after peroral Lactobacillus rhamnosus GG consumption, a pilot study. Int Forum Allergy Rhinol 6(8):848-853. https://doi.org/10.1002/alr.21748

20. Turner RB, Woodfolk JA, Borish L, Steinke JW, Patrie JT, Muehling LM, Lahtinen S, Lehtinen MJ (2017) Effect of probiotic on innate inflammatory response and viral shedding in experimental rhinovirus infection-a randomised controlled trial. Benef Microbes 8(2):207-215. https://doi.org/10.3920/BM2016.0160

21. Wang B, Hylwka T, Smieja M, Surrette M, Bowdish DME, Loeb M (2018) Probiotics to prevent respiratory infections in nursing homes: a pilot randomized controlled trial. J Am Geriatr Soc 66(7):1346-1352. https://doi.org/10.1111/jgs.15396

22. Kumpu M, Kekkonen RA, Korpela R, Tynkkynen S, Jarvenpaa S, Kautiainen H, Allen EK, Hendley JO, Pitkaranta A, Winther B (2015) Effect of live and inactivated Lactobacillus rhamnosus GG on experimentally induced rhinovirus colds: randomised, double blind, placebo-controlled pilot trial. Benef Microbes 6(5):631-639. https://doi.org/10.3920/BM2014.0164

23. Kumpu M, Lehtoranta L, Roivainen M, Ronkko E, Ziegler T, Soderlund-Venermo M, Kautiainen H, Jarvenpaa S, Kekkonen R, Hatakka K, Korpela R, Pitkaranta A (2013) The use of the probiotic Lactobacillus rhamnosus GG and viral findings in the nasopharynx of children attending day care. J Med Virol 85(9):1632-1638. https://doi.org/10.1002/jmv.23623

24. Lehtoranta L, Kalima K, He L, Lappalainen M, Roivainen M, Narkio M, Makela M, Siitonen S, Korpela R, Pitkaranta A (2014) Specific probiotics and virological findings in symptomatic conscripts attending military service in Finland. J Clin Virol 60(3):276-281. https://doi.org/10.1016/j.jcv.2014.03.021

25. Luoto R, Ruuskanen O, Waris M, Kalliomaki M, Salminen S, Isolauri E (2014) Prebiotic and probiotic supplementation prevents rhinovirus infections in preterm infants: a randomized, placebo-controlled trial. J Allergy Clin Immunol 133(2):405413. https://doi.org/10.1016/j.jaci.2013.08.020

26. Sugimura T, Takahashi H, Jounai K, Ohshio K, Kanayama M, Tazumi K, Tanihata Y, Miura Y, Fujiwara D, Yamamoto N (2015) Effects of oral intake of plasmacytoid dendritic cellsstimulative lactic acid bacterial strain on pathogenesis of influenza-like illness and immunological response to influenza virus. Br J Nutr 114(5):727-733. https://doi.org/10.1017/S000711451 5002408

27. Shida K, Sato T, Iizuka R, Hoshi R, Watanabe O, Igarashi T, Miyazaki K, Nanno M, Ishikawa F (2017) Daily intake of fermented milk with Lactobacillus casei strain Shirota reduces the incidence and duration of upper respiratory tract infections in healthy middle-aged office workers. Eur J Nutr 56(1):45-53. https://doi.org/10.1007/s00394-015-1056-1

28. Yamamoto Y, Saruta J, Takahashi T, To M, Shimizu T, Hayashi T, Morozumi T, Kubota N, Kamata Y, Makino S, Kano H, Hemmi J, Asami Y, Nagai T, Misawa K, Kato S, Tsukinoki K (2019) Effect of ingesting yogurt fermented with Lactobacillus delbrueckii ssp. bulgaricus OLL1073R-1 on influenza virusbound salivary $\operatorname{IgA}$ in elderly residents of nursing homes: a randomized controlled trial. Acta Odontol Scand 77(7):517-524. https://doi.org/10.1080/00016357.2019.1609697

29. Belkacem N, Bourdet-Sicard R, Taha MK (2018) Lactobacillus paracasei feeding improves the control of secondary experimental meningococcal infection in flu-infected mice. BMC Infect Dis 18(1):167. https://doi.org/10.1186/s12879-018-3086-9

30. Eguchi K, Fujitani N, Nakagawa H, Miyazaki T (2019) Prevention of respiratory syncytial virus infection with probiotic lactic acid bacterium Lactobacillus gasseri SBT2055. Sci Rep 9(1):4812. https://doi.org/10.1038/s41598-019-39602-7

31. Fujimura KE, Demoor T, Rauch M, Faruqi AA, Jang S, Johnson CC, Boushey HA, Zoratti E, Ownby D, Lukacs NW, Lynch SV (2014) House dust exposure mediates gut microbiome Lactobacillus enrichment and airway immune defense against allergens and virus infection. Proc Natl Acad Sci U S A 111(2):805-810. https://doi.org/10.1073/pnas.1310750111

32. Takahashi E, Sawabuchi T, Kimoto T, Sakai S, Kido H (2019) Lactobacillus delbrueckii ssp. bulgaricus OLL1073R-1 feeding enhances humoral immune responses, which are suppressed by the antiviral neuraminidase inhibitor oseltamivir in influenza A virus-infected mice. J Dairy Sci 102(11):9559-9569. https://doi. org/10.3168/jds.2019-16268

33. Takeda S, Takeshita M, Kikuchi Y, Dashnyam B, Kawahara S, Yoshida H, Watanabe W, Muguruma M, Kurokawa M (2011) Efficacy of oral administration of heat-killed probiotics from Mongolian dairy products against influenza infection in mice: alleviation of influenza infection by its immunomodulatory activity through intestinal immunity. Int Immunopharmacol 11(12):1976-1983. https://doi.org/10.1016/j.intimp.2011.08.007

34. Waki N, Yajima N, Suganuma H, Buddle BM, Luo D, Heiser A, Zheng T (2014) Oral administration of Lactobacillus brevis KB290 to mice alleviates clinical symptoms following influenza virus infection. Lett Appl Microbiol 58(1):87-93. https://doi.org/ 10.1111/lam. 12160

35. Youn HN, Lee DH, Lee YN, Park JK, Yuk SS, Yang SY, Lee HJ, Woo SH, Kim HM, Lee JB, Park SY, Choi IS, Song CS (2012) Intranasal administration of live Lactobacillus species facilitates protection against influenza virus infection in mice. Antiviral Res 93(1):138-143. https://doi.org/10.1016/j.antiviral.2011.11.004

36. Zelaya H, Tsukida K, Chiba E, Marranzino G, Alvarez S, Kitazawa H, Aguero G, Villena J (2014) Immunobiotic lactobacilli reduce viral-associated pulmonary damage through the modulation of inflammation-coagulation interactions. Int Immunopharmacol 19(1):161-173. https://doi.org/10.1016/j.intimp. 2013.12.020 
37. Iwabuchi N, Yonezawa S, Odamaki T, Yaeshima T, Iwatsuki K, Xiao JZ (2012) Immunomodulating and anti-infective effects of a novel strain of Lactobacillus paracasei that strongly induces interleukin-12. FEMS Immunol Med Microbiol 66(2):230 239. https://doi.org/10.1111/j.1574-695X.2012.01003.x

38. Kawase M, He F, Kubota A, Harata G, Hiramatsu M (2010) Oral administration of lactobacilli from human intestinal tract protects mice against influenza virus infection. Lett Appl Microbiol 51(1):6-10. https://doi.org/10.1111/j.1472-765X. 2010.02849.x

39. Kawase M, He F, Kubota A, Yoda K, Miyazawa K, Hiramatsu M (2012) Heat-killed Lactobacillus gasseri TMC0356 protects mice against influenza virus infection by stimulating gut and respiratory immune responses. FEMS Immunol Med Microbiol 64(2):280-288. https://doi.org/10.1111/j.1574-695X.2011. 00903.x

40. Kawashima T, Hayashi K, Kosaka A, Kawashima M, Igarashi T, Tsutsui H, Tsuji NM, Nishimura I, Hayashi T, Obata A (2011) Lactobacillus plantarum strain YU from fermented foods activates Th1 and protective immune responses. Int Immunopharmacol 11(12):2017-2024. https://doi.org/10.1016/j.intimp.2011. 08.013

41. Kechaou N, Chain F, Gratadoux JJ, Blugeon S, Bertho N, Chevalier C, Le Goffic R, Courau S, Molimard P, Chatel JM, Langella P, Bermudez-Humaran LG (2013) Identification of one novel candidate probiotic Lactobacillus plantarum strain active against influenza virus infection in mice by a large-scale screening. Appl Environ Microbiol 79(5):1491-1499. https://doi.org/10.1128/ AEM.03075-12

42. Kikuchi Y, Kunitoh-Asari A, Hayakawa K, Imai S, Kasuya K, Abe K, Adachi Y, Fukudome S, Takahashi Y, Hachimura S (2014) Oral administration of Lactobacillus plantarum strain AYA enhances IgA secretion and provides survival protection against influenza virus infection in mice. PLoS ONE 9(1):e86416. https://doi.org/10.1371/journal.pone.0086416

43. Kiso M, Takano R, Sakabe S, Katsura H, Shinya K, Uraki R, Watanabe S, Saito H, Toba M, Kohda N, Kawaoka Y (2013) Protective efficacy of orally administered, heat-killed Lactobacillus pentosus b240 against influenza A virus. Sci Rep 3:1563. https:// doi.org/10.1038/srep01563

44. Kobayashi N, Saito T, Uematsu T, Kishi K, Toba M, Kohda N, Suzuki T (2011) Oral administration of heat-killed Lactobacillus pentosus strain b240 augments protection against influenza virus infection in mice. Int Immunopharmacol 11(2):199-203. https:// doi.org/10.1016/j.intimp.2010.11.019

45. Maeda N, Nakamura R, Hirose Y, Murosaki S, Yamamoto Y, Kase T, Yoshikai Y (2009) Oral administration of heat-killed Lactobacillus plantarum L-137 enhances protection against influenza virus infection by stimulation of type I interferon production in mice. Int Immunopharmacol 9(9):1122-1125. https:// doi.org/10.1016/j.intimp.2009.04.015

46. Nagai T, Makino S, Ikegami S, Itoh H, Yamada H (2011) Effects of oral administration of yogurt fermented with Lactobacillus delbrueckii ssp. bulgaricus OLL1073R-1 and its exopolysaccharides against influenza virus infection in mice. Int Immunopharmacol 11(12):2246-2250. https://doi.org/10.1016/j.intimp.2011. 09.012

47. Nakayama Y, Moriya T, Sakai F, Ikeda N, Shiozaki T, Hosoya T, Nakagawa H, Miyazaki T (2014) Oral administration of Lactobacillus gasseri SBT2055 is effective for preventing influenza in mice. Sci Rep 4:4638. https://doi.org/10.1038/srep04638

48. Park MK, Ngo V, Kwon YM, Lee YT, Yoo S, Cho YH, Hong SM, Hwang HS, Ko EJ, Jung YJ, Moon DW, Jeong EJ, Kim MC, Lee YN, Jang JH, Oh JS, Kim CH, Kang SM (2013) Lactobacillus plantarum DK119 as a probiotic confers protection against influenza virus by modulating innate immunity. PLoS
ONE 8(10):e75368. https://doi.org/10.1371/journal.pone.00753 68

49. Park S, Kim JI, Bae JY, Yoo K, Kim H, Kim IH, Park MS, Lee I (2018) Effects of heat-killed Lactobacillus plantarum against influenza viruses in mice. J Microbiol 56(2):145-149. https://doi. org/10.1007/s12275-018-7411-1

50. Poorbaghi SL, Dadras H, Gheisari HR, Mosleh N, Firouzi S, Roohallazadeh H (2014) Effects of Lactobacillus acidophilus and inulin on faecal viral shedding and immunization against H9 N2 Avian influenza virus. J Appl Microbiol 116(3):667-676. https:// doi.org/10.1111/jam.12390

51. Song JA, Kim HJ, Hong SK, Lee DH, Lee SW, Song CS, Kim KT, Choi IS, Lee JB, Park SY (2016) Oral intake of Lactobacillus rhamnosus M21 enhances the survival rate of mice lethally infected with influenza virus. J Microbiol Immunol Infect 49(1):16-23. https://doi.org/10.1016/j.jmii.2014.07.011

52. Hori T, Kiyoshima J, Shida K, Yasui H (2002) Augmentation of cellular immunity and reduction of influenza virus titer in aged mice fed Lactobacillus casei strain Shirota. Clin Diagn Lab Immunol 9(1):105-108. https://doi.org/10.1128/cdli.9.1. 105-108.2002

53. Yasui H, Kiyoshima J, Hori T (2004) Reduction of influenza virus titer and protection against influenza virus infection in infant mice fed Lactobacillus casei Shirota. Clin Diagn Lab Immunol 11(4):675-679. https://doi.org/10.1128/CDLI.11.4. 675-679.2004

54. Chiba E, Tomosada Y, Vizoso-Pinto MG, Salva S, Takahashi T, Tsukida K, Kitazawa H, Alvarez S, Villena J (2013) Immunobiotic Lactobacillus rhamnosus improves resistance of infant mice against respiratory syncytial virus infection. Int Immunopharmacol 17(2):373-382. https://doi.org/10.1016/j.intimp.2013.06.024

55. Belkacem N, Serafini N, Wheeler R, Derrien M, Boucinha L, Couesnon A, Cerf-Bensussan N, Gomperts Boneca I, Di Santo JP, Taha MK, Bourdet-Sicard R (2017) Lactobacillus paracasei feeding improves immune control of influenza infection in mice. PLoS ONE 12(9):e0184976. https://doi.org/10.1371/journ al.pone. 0184976

56. Iwabuchi N, Xiao JZ, Yaeshima T, Iwatsuki K (2011) Oral administration of Bifidobacterium longum ameliorates influenza virus infection in mice. Biol Pharm Bull 34(8):1352-1355. https://doi.org/10.1248/bpb.34.1352

57. Kawahara T, Takahashi T, Oishi K, Tanaka H, Masuda M, Takahashi S, Takano M, Kawakami T, Fukushima K, Kanazawa H, Suzuki T (2015) Consecutive oral administration of Bifidobacterium longum MM-2 improves the defense system against influenza virus infection by enhancing natural killer cell activity in a murine model. Microbiol Immunol 59(1):1-12. https://doi.org/ 10.1111/1348-0421.12210

58. Mahooti M, Abdolalipour E, Salehzadeh A, Mohebbi SR, Gorji A, Ghaemi A (2019) Immunomodulatory and prophylactic effects of Bifidobacterium bifidum probiotic strain on influenza infection in mice. World J Microbiol Biotechnol 35(6):91. https:// doi.org/10.1007/s11274-019-2667-0

59. Chen MF, Weng KF, Huang SY, Liu YC, Tseng SN, Ojcius DM, Shih SR (2017) Pretreatment with a heat-killed probiotic modulates monocyte chemoattractant protein- 1 and reduces the pathogenicity of influenza and enterovirus 71 infections. Mucosal Immunol 10(1):215-227. https://doi.org/10.1038/mi.2016.31

60. Ermolenko EI, Desheva YA, Kolobov AA, Kotyleva MP, Sychev IA, Suvorov AN (2019) Anti-influenza activity of enterocin b in vitro and protective effect of bacteriocinogenic enterococcal probiotic strain on influenza infection in mouse model. Probiotics Antimicrob Proteins 11(2):705-712. https://doi.org/10.1007/ s12602-018-9457-0

61. Kondoh M, Fukada K, Fujikura D, Shimada T, Suzuki Y, Iwai A, Miyazaki T (2012) Effect of water-soluble fraction from 
lysozyme-treated Enterococcus faecalis FK-23 on mortality caused by influenza A virus in mice. Viral Immunol 25(1):86-90. https://doi.org/10.1089/vim.2011.0056

62. Jounai K, Sugimura T, Ohshio K, Fujiwara D (2015) Oral administration of Lactococcus lactis subsp. lactis JCM5805 enhances lung immune response resulting in protection from murine parainfluenza virus infection. PLoS ONE 10(3):e0119055. https://doi.org/10.1371/journal.pone.0119055

63. Maruo T, Gotoh Y, Nishimura H, Ohashi S, Toda T, Takahashi K (2012) Oral administration of milk fermented with Lactococcus lactis subsp. cremoris FC protects mice against influenza virus infection. Lett Appl Microbiol 55(2):135-140. https://doi.org/10. 1111/j.1472-765X.2012.03270.x

64. Grayson MH, Camarda LE, Hussain SA, Zemple SJ, Hayward M, Lam V, Hunter DA, Santoro JL, Rohlfing M, Cheung DS, Salzman NH (2018) Intestinal microbiota disruption reduces regulatory $\mathrm{T}$ cells and increases respiratory viral infection mortality through increased IFNgamma production. Front Immunol 9:1587. https://doi.org/10.3389/fimmu.2018.01587

65. Abt MC, Osborne LC, Monticelli LA, Doering TA, Alenghat T, Sonnenberg GF, Paley MA, Antenus M, Williams KL, Erikson J, Wherry EJ, Artis D (2012) Commensal bacteria calibrate the activation threshold of innate antiviral immunity. Immunity 37(1):158-170. https://doi.org/10.1016/j.immuni.2012.04.011

66. Ichinohe T, Pang IK, Kumamoto Y, Peaper DR, Ho JH, Murray TS, Iwasaki A (2011) Microbiota regulates immune defense against respiratory tract influenza A virus infection. Proc Natl Acad Sci U S A 108(13):5354-5359. https://doi.org/10.1073/ pnas. 1019378108

67. Makino S, Ikegami S, Kume A, Horiuchi H, Sasaki H, Orii N (2010) Reducing the risk of infection in the elderly by dietary intake of yoghurt fermented with Lactobacillus delbrueckii ssp. bulgaricus OLL1073R-1. Br J Nutr 104(7):998-1006. https://doi. org/10.1017/S000711451000173X

68. Yitbarek A, Taha-Abdelaziz K, Hodgins DC, Read L, Nagy E, Weese JS, Caswell JL, Parkinson J, Sharif S (2018) Author correction: gut microbiota-mediated protection against influenza virus subtype $\mathrm{H} 9 \mathrm{~N} 2$ in chickens is associated with modulation of the innate responses. Sci Rep 8(1):16367. https://doi.org/10. 1038/s41598-018-34065-8

69. Li H, Liu X, Chen F, Zuo K, Wu C, Yan Y, Chen W, Lin W, Xie Q (2018) Avian influenza virus subtype H9N2 affects intestinal microbiota, barrier structure injury, and inflammatory intestinal disease in the chicken ileum. Viruses. https://doi.org/10.3390/ v10050270

70. Fejer G, Drechsel L, Liese J, Schleicher U, Ruzsics Z, Imelli N, Greber UF, Keck S, Hildenbrand B, Krug A, Bogdan C, Freudenberg MA (2008) Key role of splenic myeloid DCs in the IFN-alphabeta response to adenoviruses in vivo. PLoS Pathog 4(11):e1000208. https://doi.org/10.1371/journal.ppat.1000208

71. Wang Z, Chai W, Burwinkel M, Twardziok S, Wrede P, Palissa C, Esch B, Schmidt MF (2013) Inhibitory influence of Enterococcus faecium on the propagation of swine influenza A virus in vitro. PLoS ONE 8(1):e53043. https://doi.org/10.1371/journ al.pone. 0053043

72. Groves HT, Cuthbertson L, James P, Moffatt MF, Cox MJ, Tregoning JS (2018) Respiratory disease following viral lung infection alters the murine gut microbiota. Front Immunol 9:182. https://doi.org/10.3389/fimmu.2018.00182

73. Wu S, Jiang ZY, Sun YF, Yu B, Chen J, Dai CQ, Wu XL, Tang XL, Chen XY (2013) Microbiota regulates the TLR7 signaling pathway against respiratory tract influenza $\mathrm{A}$ virus infection. Curr Microbiol 67(4):414-422. https://doi.org/10.1007/ s00284-013-0380-z

74. Gao X, Huang L, Zhu L, Mou C, Hou Q, Yu Q (2016) Inhibition of $\mathrm{H} 9 \mathrm{~N} 2$ virus invasion into dendritic cells by the S-layer protein from L. acidophilus ATCC 4356. Front Cell Infect Microbiol 6:137. https://doi.org/10.3389/fcimb.2016.00137

75. Fuglsang E, Pizzolla A, Krych L, Nielsen DS, Brooks AG, Frokiaer H, Reading PC (2018) Changes in gut microbiota prior to influenza A virus infection do not affect immune responses in pups or juvenile mice. Front Cell Infect Microbiol 8:319. https:// doi.org/10.3389/fcimb.2018.00319

76. Yitbarek A, Alkie T, Taha-Abdelaziz K, Astill J, RodriguezLecompte JC, Parkinson J, Nagy E, Sharif S (2018) Gut microbiota modulates type I interferon and antibody-mediated immune responses in chickens infected with influenza virus subtype H9N2. Benef Microbes 9(3):417-427. https://doi.org/10.3920/ BM2017.0088

77. Jiang TT, Shao TY, Ang WXG, Kinder JM, Turner LH, Pham G, Whitt J, Alenghat T, Way SS (2017) Commensal fungi recapitulate the protective benefits of intestinal bacteria. Cell Host Microbe 22(6):809-816 e804. https://doi.org/10.1016/j.chom. 2017.10.013

78. Pang P, Yu B, Shi Y, Deng L, Xu H, Wu S, Chen X (2018) Alteration of intestinal flora stimulates pulmonary micrornas to interfere with host antiviral immunity in influenza. Molecules. https://doi.org/10.3390/molecules23123151

79. Bradley KC, Finsterbusch K, Schnepf D, Crotta S, Llorian M, Davidson S, Fuchs SY, Staeheli P, Wack A (2019) Microbiotadriven tonic interferon signals in lung stromal cells protect from influenza virus infection. Cell Rep 28(1):245-256 e244. https:// doi.org/10.1016/j.celrep.2019.05.105

80. Lynch JP, Werder RB, Loh Z, Sikder MAA, Curren B, Zhang V, Rogers MJ, Lane K, Simpson J, Mazzone SB, Spann K, Hayball J, Diener K, Everard ML, Blyth CC, Forstner C, Dennis PG, Murtaza N, Morrison M, P OC, Zhang P, Haque A, Hill GR, Sly PD, Upham JW, Phipps S, (2018) Plasmacytoid dendritic cells protect from viral bronchiolitis and asthma through semaphorin 4a-mediated T reg expansion. J Exp Med 215(2):537-557. https://doi.org/10.1084/jem.20170298

81. Figueroa T, Bessiere P, Coggon A, Bouwman KM, van der Woude R, Delverdier M, Verheije MH, de Vries RP, Volmer R (2020) The microbiota contributes to the control of highly pathogenic H5N9 influenza virus replication in ducks. J Virol. https:// doi.org/10.1128/JVI.00289-20

82. Hill C, Guarner F, Reid G, Gibson GR, Merenstein DJ, Pot B, Morelli L, Canani RB, Flint HJ, Salminen S, Calder PC, Sanders ME (2014) Expert consensus document: The international scientific association for probiotics and prebiotics consensus statement on the scope and appropriate use of the term probiotic. Nat Rev Gastroenterol Hepatol 11(8):506-514

83. Maldonado Galdeano C, Cazorla SI, Lemme Dumit JM, Velez E, Perdigon G (2019) Beneficial effects of probiotic consumption on the immune system. Ann Nutr Metab 74(2):115-124. https:// doi.org/10.1159/000496426

84. Kang S, Brown HM, Hwang S (2018) Direct antiviral mechanisms of interferon-gamma. Immune Netw 18(5):e33. https:// doi.org/10.4110/in.2018.18.e33

85. Parada Venegas D, De la Fuente MK, Landskron G, Gonzalez MJ, Quera R, Dijkstra G, Harmsen HJM, Faber KN, Hermoso MA (2019) Corrigendum: Short Chain Fatty Acids (SCFAs)mediated gut epithelial and immune regulation and its relevance for inflammatory bowel diseases. Front Immunol 10:1486. https://doi.org/10.3389/fimmu.2019.01486

86. Sencio V, Barthelemy A, Tavares LP, Machado MG, Soulard D, Cuinat C, Queiroz-Junior CM, Noordine ML, Salome-Desnoulez S, Deryuter L, Foligne B, Wahl C, Frisch B, Vieira AT, Paget C, Milligan G, Ulven T, Wolowczuk I, Faveeuw C, Le Goffic R, Thomas M, Ferreira S, Teixeira MM, Trottein F (2020) Gut dysbiosis during influenza contributes to pulmonary pneumococcal superinfection through altered short-chain fatty acid production. 
Cell Rep 30(9):2934-2947 e2936. https://doi.org/10.1016/j.celrep.2020.02.013

87. Antunes KH, Fachi JL, de Paula R, da Silva EF, Pral LP, Dos Santos AA, Dias GBM, Vargas JE, Puga R, Mayer FQ, Maito F, Zarate-Blades CR, Ajami NJ, Sant'Ana MR, Candreva T, Rodrigues HG, Schmiele M, Silva Clerici MTP, Proenca-Modena JL, Vieira AT, Mackay CR, Mansur D, Caballero MT, Marzec J, Li J, Wang X, Bell D, Polack FP, Kleeberger SR, Stein RT, Vinolo MAR, de Souza APD (2019) Microbiota-derived acetate protects against respiratory syncytial virus infection through a GPR43type 1 interferon response. Nat Commun 10(1):3273. https://doi. org/10.1038/s41467-019-11152-6

88. Hirose Y, Yamamoto Y, Yoshikai Y, Murosaki S (2013) Oral intake of heat-killed Lactobacillus plantarum L-137 decreases the incidence of upper respiratory tract infection in healthy subjects with high levels of psychological stress. J Nutr Sci 2:e39. https://doi.org/10.1017/jns.2013.35

89. Capurso L (2019) Thirty years of Lactobacillus rhamnosus GG: a review. J Clin Gastroenterol 53(Suppl 1):S1-s41. https://doi. org $/ 10.1097 / \mathrm{mcg} .0000000000001170$

90. Suez J, Zmora N, Segal E (2019) The pros, cons, and many unknowns of probiotics. Nat Med 25(5):716-729. https://doi. org/10.1038/s41591-019-0439-x

91. Piqué N, Berlanga M, Miñana-Galbis D (2019) Health benefits of heat-killed (tyndallized) probiotics: an overview. Int J Mol Sci. https://doi.org/10.3390/ijms20102534

92. Lehtoranta L, Latvala S, Lehtinen MJ (2020) Role of probiotics in stimulating the immune system in viral respiratory tract infections: a narrative review. Nutrients. https://doi.org/10.3390/ nu12103163

93. El Hage R, Hernandez-Sanabria E, Van de Wiele T (2017) Emerging trends in "Smart Probiotics": functional consideration for the development of novel health and industrial applications. Front Microbiol 8:1889. https://doi.org/10.3389/fmicb.2017. 01889

94. Borody TJ, Eslick GD, Clancy RL (2019) Fecal microbiota transplantation as a new therapy: from Clostridioides difficile infection to inflammatory bowel disease, irritable bowel syndrome, and colon cancer. Curr Opin Pharmacol 49:43-51. https://doi. org/10.1016/j.coph.2019.04.017

95. Petrof EO, Gloor GB, Vanner SJ, Weese SJ, Carter D, Daigneault MC, Brown EM, Schroeter K, Allen-Vercoe E (2013) Stool substitute transplant therapy for the eradication of Clostridium difficile infection: "RePOOPulating" the gut. Microbiome 1(1):3. https://doi.org/10.1186/2049-2618-1-3

96. O'Toole PW, Marchesi JR, Hill C (2017) Next-generation probiotics: the spectrum from probiotics to live biotherapeutics. Nat Microbiol 2:17057. https://doi.org/10.1038/nmicrobiol.2017.57

97. Gibson GR, Hutkins R, Sanders ME, Prescott SL, Reimer RA, Salminen SJ, Scott K, Stanton C, Swanson KS, Cani PD, Verbeke K, Reid G (2017) Expert consensus document: the International Scientific Association for Probiotics and Prebiotics (ISAPP) consensus statement on the definition and scope of prebiotics. Nat Rev Gastroenterol Hepatol 14(8):491-502. https://doi.org/ 10.1038/nrgastro.2017.75

98. Shahramian I, Kalvandi G, Javaherizadeh H, Khalili M, Noori NM, Delaramnasab M, Bazi A (2018) The effects of prebiotic supplementation on weight gain, diarrhoea, constipation, fever and respiratory tract infections in the first year of life. J Paediatr Child Health 54(8):875-880. https://doi.org/10.1111/jpc.13906

99. Ranucci G, Buccigrossi V, Borgia E, Piacentini D, Visentin F, Cantarutti L, Baiardi P, Felisi M, Spagnuolo MI, Zanconato S, Baraldi E, Giaquinto C, Guarino A (2018) Galacto-oligosaccharide/polidextrose enriched formula protects against respiratory infections in infants at high risk of atopy: a randomized clinical trial. Nutrients. https://doi.org/10.3390/nu10030286
100. Arslanoglu S, Moro GE, Schmitt J, Tandoi L, Rizzardi S, Boehm G (2008) Early dietary intervention with a mixture of prebiotic oligosaccharides reduces the incidence of allergic manifestations and infections during the first two years of life. J Nutr 138(6):1091-1095. https://doi.org/10.1093/jn/138.6.1091

101. Milani C, Duranti S, Bottacini F, Casey E, Turroni F, Mahony J, Belzer C, Delgado Palacio S, Arboleya Montes S, Mancabelli L, Lugli GA, Rodriguez JM, Bode L, de Vos W, Gueimonde M, Margolles A, van Sinderen D, Ventura M (2017) The first microbial colonizers of the human gut: composition, activities, and health implications of the infant gut microbiota. Microbiol Mol Biol Rev. https://doi.org/10.1128/mmbr.00036-17

102. Schijf MA, Kruijsen D, Bastiaans J, Coenjaerts FE, Garssen J, van Bleek GM, van't Land B, (2012) Specific dietary oligosaccharides increase Th1 responses in a mouse respiratory syncytial virus infection model. J Virol 86(21):11472-11482. https://doi. org/10.1128/jvi.06708-11

103. Budden KF, Gellatly SL, Wood DL, Cooper MA, Morrison M, Hugenholtz P, Hansbro PM (2017) Emerging pathogenic links between microbiota and the gut-lung axis. Nat Rev Microbiol 15(1):55-63. https://doi.org/10.1038/nrmicro.2016.142

104. Lee JR, Huang J, Magruder M, Zhang LT, Gong C, Sholi AN, Albakry S, Edusei E, Muthukumar T, Lubetzky M, Dadhania DM, Taur Y, Pamer EG, Suthanthiran M (2019) Butyrateproducing gut bacteria and viral infections in kidney transplant recipients: a pilot study. Transpl Infect Dis 21(6):e13180. https:// doi.org/10.1111/tid.13180

105. Haak BW, Littmann ER, Chaubard JL, Pickard AJ, Fontana E, Adhi F, Gyaltshen Y, Ling L, Morjaria SM, Peled JU, van den Brink MR, Geyer AI, Cross JR, Pamer EG, Taur Y (2018) Impact of gut colonization with butyrate-producing microbiota on respiratory viral infection following allo-HCT. Blood 131(26):29782986. https://doi.org/10.1182/blood-2018-01-828996

106. Ogimi C, Krantz EM, Golob JL, Waghmare A, Liu C, Leisenring WM, Woodard CR, Marquis S, Kuypers JM, Jerome KR, Pergam SA, Fredricks DN, Sorror ML, Englund JA, Boeckh M (2018) Antibiotic exposure prior to respiratory viral infection is associated with progression to lower respiratory tract disease in allogeneic hematopoietic cell transplant recipients. Biol Blood Marrow Transplant 24(11):2293-2301. https://doi.org/10.1016/j. bbmt.2018.05.016

107. Wang J, Li F, Wei H, Lian ZX, Sun R, Tian Z (2014) Respiratory influenza virus infection induces intestinal immune injury via microbiota-mediated Th17 cell-dependent inflammation. J Exp Med 211(12):2397-2410. https://doi.org/10.1084/jem.20140625

108. Yildiz S, Mazel-Sanchez B, Kandasamy M, Manicassamy B, Schmolke M (2018) Influenza A virus infection impacts systemic microbiota dynamics and causes quantitative enteric dysbiosis. Microbiome 6(1):9. https://doi.org/10.1186/s40168-017-0386-Z

109. Wang D, Hu B, Hu C, Zhu F, Liu X, Zhang J, Wang B, Xiang H, Cheng Z, Xiong Y, Zhao Y, Li Y, Wang X, Peng Z (2020) Clinical characteristics of 138 hospitalized patients with 2019 novel coronavirus-infected pneumonia in Wuhan, China. JAMA 323(11):1061-1069. https://doi.org/10.1001/jama.2020.1585

110. Wong SH, Lui RN, Sung JJ (2020) Covid-19 and the digestive system. J Gastroenterol Hepatol 35(5):744-748. https://doi.org/ 10.1111/jgh. 15047

111. Ma C, Cong Y, Zhang H (2020) COVID-19 and the digestive system. Am J Gastroenterol. https://doi.org/10.14309/ajg.00000 00000000691

112. Zuo T, Zhang F, Lui GCY, Yeoh YK, Li AYL, Zhan H, Wan Y, Chung A, Cheung CP, Chen N, Lai CKC, Chen Z, Tso EYK, Fung KSC, Chan V, Ling L, Joynt G, Hui DSC, Chan FKL, Chan PKS, Ng SC (2020) Alterations in gut microbiota of patients with COVID-19 during time of hospitalization. Gastroenterology. https://doi.org/10.1053/j.gastro.2020.05.048 
113. Xu K, Cai H, Shen Y, Ni Q, Chen Y, Hu S, Li J, Wang H, Yu L, Huang H, Qiu Y, Wei G, Fang Q, Zhou J, Sheng J, Liang T, Li L (2020) [Management of corona virus disease-19 (COVID-19): the Zhejiang experience]. Zhejiang Da Xue Xue Bao Yi Xue Ban 49 (1):0

114. Dhar D, Mohanty A (2020) Gut microbiota and Covid-19- possible link and implications. Virus Res 285:198018. https://doi. org/10.1016/j.virusres.2020.198018

115. Mak JWY, Chan FKL, Ng SC (2020) Probiotics and COVID-19: one size does not fit all. Lancet Gastroenterol Hepatol. https:// doi.org/10.1016/s2468-1253(20)30122-9

116. d'Ettorre G, Ceccarelli G, Marazzato M, Campagna G, Pinacchio C, Alessandri F, Ruberto F, Rossi G, Celani L, Scagnolari C,
Mastropietro C, Trinchieri V, Recchia GE, Mauro V, Antonelli G, Pugliese F, Mastroianni CM (2020) Challenges in the management of SARS-CoV2 infection: the role of oral bacteriotherapy as complementary therapeutic strategy to avoid the progression of COVID-19. Front Med (Lausanne) 7:389. https://doi.org/10. 3389/fmed.2020.00389

117. Xu Z, Chan FK, Ng SC (2021) Reply: dysbiosis in SARS-CoV-2 infected patients. Gastroenterology. https://doi.org/10.1053/j.gastro.2021.01.198

118. Hanada S, Pirzadeh M, Carver KY, Deng JC (2018) Respiratory viral infection-induced microbiome alterations and secondary bacterial pneumonia. Front Immunol 9:2640. https://doi.org/10. 3389/fimmu.2018.02640 